NBER WORKING PAPER SERIES

\title{
WHY DON'T HOUSEHOLDS SMOOTH CONSUMPTION? EVIDENCE FROM A 25 MILLION DOLLAR EXPERIMENT
}

\author{
Jonathan Parker \\ Working Paper 21369 \\ http://www.nber.org/papers/w21369 \\ NATIONAL BUREAU OF ECONOMIC RESEARCH \\ 1050 Massachusetts Avenue \\ Cambridge, MA 02138 \\ July 2015 \\ Revised February 2017
}

For helpful comments, I thank Christian Broda, Chris Carroll, Peter Hansen, John Heaton, Olivia Kim, Holger Mueller, Nicholas Souleles, Jeremy Tobacman, Steven Zeldes, the referees at this Journal, two anonymous referees on the survey grant application, and participants at seminars the Consumer Financial Protection Bureau, the Federal Reserve Bank of Boston, Chicago, Columbia, Harvard, MIT, NYU, Pennsylvania, Stanford, Yale, and the NBER Household Finance meetings July 2014. I thank the MIT Sloan School of Management, the Kellogg School of Management at Northwestern University, the Initiative for Global Markets at the University of Chicago, and the Zell Center at the Kellogg School of Management for funding. I thank Ed Grove, Matt Knain and Molly Hagen at Nielsen for their work on the survey and their careful explanation of the Nielsen Consumer Panel. The results of this paper are calculated based on data from The Nielsen Company (U.S.) LLC and provided by the Marketing Data Center and the University of Chicago Booth School of Business. The views expressed herein are those of the author and do not necessarily reflect the views of the National Bureau of Economic Research.

NBER working papers are circulated for discussion and comment purposes. They have not been peer-reviewed or been subject to the review by the NBER Board of Directors that accompanies official NBER publications.

(C) 2015 by Jonathan Parker. All rights reserved. Short sections of text, not to exceed two paragraphs, may be quoted without explicit permission provided that full credit, including () notice, is given to the source. 
Why Don't Households Smooth Consumption? Evidence from a 25 Million Dollar Experiment Jonathan Parker

NBER Working Paper No. 21369

July 2015, Revised February 2017

JEL No. D14,E21

\begin{abstract}
$\underline{\text { ABSTRACT }}$
This paper evaluates theoretical explanations for the propensity of households to increase spending in response to the arrival of predictable, lump-sum payments, using households in the Nielsen Consumer Panel who received 25 million in randomly-distributed stimulus payments. The pattern of spending is inconsistent with models in which identical households cycle rapidly through high and low response states as they manage liquidity, but is instead highly predictable by income years before the payment. Spending responses are unrelated to expectation errors, almost unrelated to crude measures of procrastination and self-control, significantly related to sophistication and planning, and highly related to impatience.
\end{abstract}

Jonathan Parker

MIT Sloan School of Management

100 Main Street, E62-642

Cambridge, MA 02142-1347

and NBER

JAParker@MIT.edu 
The canonical assumption that the benefits of additional consumption decline with the level of consumption - that marginal utility is diminishing - implies that people should manage liquidity to stabilize their consumption over time. While many issues complicate testing, this proposition of consumption smoothing has been frequently rejected: on average, predictable changes in household income or liquidity cause significant changes in household spending, with the causal effects concentrated among households with low liquid wealth or low income. ${ }^{1}$ This paper investigates why.

One possibility is that illiquidity and lack of consumption smoothing are purely the result of poor income shocks or temporary portfolio illiquidity, as in the textbook buffer stock model or life-cycle/permanent income model (LCPIH) with borrowing constraints (e.g., Zeldes, 1989b; Deaton, 1991; Carroll, 1997). Similar predictions follow from a model in which households have costly access to high-return, relatively illiquid savings vehicles (Kaplan and Violante, 2014). When preferences are homogeneous, lack of consumption smoothing is entirely due to temporarily low liquidity.

An alternative hypothesis is that low liquidity and lack of consumption smoothing are persistent household traits, significantly due to preferences or behavioral characteristics rather than being only situational. The most straightforward version of such a theory is that some households are highly impatient or hand to mouth households as in Campbell and Mankiw (1989), Krusell and Smith (1998), and Hurst (2003). Other theories motivated by evidence from laboratory experiments and neurological studies characterize lack of consumption smoothing as due to the limits of human reasoning or the complexity of human motivation in economic behaviors. As examples, lack of consumption smoothing may be due to limited attention, limited planning, reliance on heuristics, or problems of self-control (e.g., Caballero, 1995; Reis, 2006; Lusardi, 1999; Ameriks, Caplin and Leahy, 2003; Angeletos et al., 2001; Gul and Pesendorfer, 2004a,b). While according to the homogeneousagent model, some people are unable to smooth consumption due to temporarily low liquid wealth, according to these alternatives, some people choose not to smooth consumption and not to accumulate liquid wealth due to persistent behavioral characteristics.

This paper studies why household spending responds to liquidity using a setting in which lack of consumption smoothing has already been documented (Broda and Parker, 2014): a natural field experiment provided by disbursement of the Federal economic stimulus payments of 2008. Using data from a specially-designed survey of households that are reporting spending in the Nielsen Consumer Panel (NCP, formerly the Homescan Consumer Panel), I find evidence that the spending response of a household to the arrival of a payment is related to household status two years prior to the experiment, consistent with the behavior being caused by persistent characteristics (like preferences) rather than solely by temporarily low income. What characteristics? Spending responses to liquidity in this experiment are not significantly associated with expectations errors (mis-estimation of payment amount), or with measures of procrastination or lack of self-control. Instead, lack of consumption smoothing is associated with a measure of impatience, a measure of lack of financial plan-

\footnotetext{
${ }^{1}$ Most studies examine increases in liquidity caused by predictable increases in income (Zeldes, 1989a; Shapiro and Slemrod, 1995; Parker, 1999; Souleles, 1999; Johnson, Parker and Souleles, 2006; Stephens, 2003; Jappelli and Pistaferri, 2014). Other studies have studied increases in liquidity caused by predictable increase in spending costs Souleles (2000), changes in credit constraints (Gross and Souleles, 2002; Ludvigson, 1999), or predictable decreases in loan payments (Stephens, 2008; Di Maggio, Kermani and Ramcharan, 2015; Keys et al., 2014).
} 
ning, and some measures of lack of frictionless optimization in other dimensions.

I measure the degree of consumption smoothing from the response of a household's spendingto the receipt of an Economic Stimulus Payment using near-random variation in the timing of receipt. ${ }^{2}$ Among households receiving stimulus payments by check and among those receiving payments by direct deposit, the week in which the payment was disbursed was determined by the last two digits of the recipient's Social Security number, digits which are effectively randomly assigned. Following previous research, I compare the spending patterns of households who receive their payments at different times. Because the timing of the payment is randomly set by the government and is unrelated to a household's characteristics or economic situation, this comparison measures the increase in spending caused by receipt. Because the variation in timing is uncorrelated with household characteristics, comparing differences in spending responses across households with different characteristics measures how spending responses to liquidity differ by household characteristic.

The NCP data contain daily information on each household's purchases of household items as well as annual demographic information such as family size and income. In conjunction with Nielsen, a multi-wave survey was designed early in 2008 and then fielded while the stimulus payments were being disbursed in 2008. The survey, administered by email and web for households with web access at home, and by mail and barcode scanner for households without, collected information on i) the arrival and amount of the first stimulus payment received in order to measure the spending response to the payment, and ii) the liquid wealth, behaviors, and expectations of households in order to relate these characteristics to the failure to smooth consumption spending. After dropping households that did not receive payments or did not report valid payments, the supplemental survey measures more than 25 thousand NCP households in 2008 as they receive more than 25 million dollars in randomly-timed stimulus payments.

On average, the spending of households that receive their payments early rises relative to the spending of households that receive their payments later. ${ }^{3}$ If spending responses were similar across households, then cross-sectional data on household responses would tell us little about behavioral models. In fact, consistent with previous research, the majority of the average spending response is due to households with low liquidity, who spend at a rate three to four times that of liquid households on arrival. Thus, for any other characteristic to be the cause of spending responses, it must exhibit variation across households. And this variation must be correlated with liquidity in order to explain a substantial share of the average spending response. The main findings, summarized in Table 11 in the concluding section, are as follows.

The first main result is that, while low liquidity is a strong predictor of large spending responses, this does not appear to be due to current poor income shocks but rather is a per-

\footnotetext{
${ }^{2}$ Following the methodology of Johnson, Parker and Souleles (2006). This approach has also been used to study these and other rebates by Agarwal, Liu and Souleles (2007); Parker et al. (2013); Broda and Parker (2014), and other outcomes by Bertrand and Morse (2009) and Gross, Notowidigdo and Wang (2014).

${ }^{3}$ Specifically, the average household raises its spending on NCP-measured household goods by around 13 dollars, roughly 9 percent of average weekly spending, or about 1.4 percent of the average payment in the week of receipt, all highly statistically significant, and by 30 dollars, 2.5 to 3 percent of spending, or roughly 2.5 percent of the payment cumulative over the first seven weeks. In addition to the earlier cited papers, the spending responses are also estimated by Bureau of Labor Statistics (2009) and Sahm, Shapiro and Slemrod (2010).
} 
sistent characteristic of low income households lasting years. If shocks to income cause low liquid wealth and failure to smooth spending, then declines in income ought to be correlated with spending responses. But households with low income growth are no more likely to spend the payment on arrival than those with high income growth. And while it is the case that low income in 2008 is associated with high rates of spending from payments, income in 2006 is as good as income in 2008, and as liquidity in 2008, at distinguishing households who spend from those who do not. In fact, low 2006 income predicts spending responses even conditional on liquidity. Thus the propensity to spend out of liquidity persists across years.

Second, the analysis rejects models that generate spending responses through beliefs about the payments. Few households were surprised to get payments and there is little evidence of a larger spending effect of arrival for those who were positively surprised by their payments. In one of two specifications, there is a statistically higher spending response for households who were surprised, but this higher spending response occurs whether the surprise is positive or negative. Thus, the spending response did not occur because many households, particularly low liquidity households, were surprised by their payments. Instead, the evidence is suggestive of a link between consumption smoothing and economic abilities or planning as revealed by understanding of the stimulus payment program.

Third, and related, the data provide evidence consistent with lack of planning causing violations of consumption smoothing, as in Reis (2006). Households that have not made financial plans do not smooth spending across arrival of the payment, while households that have made financial plans smooth consumption well. I also find that optimal allocation over time (relative to a frictionless baseline) is related to optimal allocation across goods. Households that typically use more deals or specials do a better job of smoothing spending the week of arrival than those that do not. This is particularly true for households with low liquidity, consistent with households differing in the degree to which they plan or optimize economic resources, with 'inattentive' households having low liquidity, low incomes, and a high propensity to spend out of liquidity. However, there is little evidence that variation in optimization or planning is a personality trait that crosses decision-making domains. Even households that report that they plan a great deal for vacations ( 22 percent of households) increase spending significantly during the month following arrival (although they do smooth spending reasonably well the week of arrival).

The fourth main finding is that the majority of lack of consumption smoothing is predicted by a simple measure that can be interpreted as impatience. Consumption smoothing is highly correlated with whether a household reports being the sort of people who would rather spend their money and enjoy today rather than save more for the future. Households that report being 'savers' smooth consumption; households that report being 'spenders' do not. Not surprisingly, being a saver is also highly correlated with the level of liquid wealth, so that the type of person is an important predictor of both low wealth and lack of consumption smoothing. And the type of people who are spenders are worse at consumption smoothing even among households with low liquidity.

Finally, the spending response is unrelated to two measures of problems of self-control and procrastination. First, the five percent of the sample that frequently regrets past purchases has an economically large (but statistically-weak) spending response to payment 
arrival. But this does not explain much of the average spending response. The other 95 percent of the population still exhibits substantial violations of consumption smoothing. Second, to analyze procrastination, I sort households by their delay in responding to the supplemental survey. This procrastination measure is unrelated to the size of spending response.

These findings have several implications for the modeling of consumption and saving behavior. First, these results reject models that generate the average spending response through surprise at the arrival of these payments. Second, in any model in which the high spending responses are situational and occur among otherwise homogeneous populations due to low liquidity, the low liquidity state has to be highly persistent year to year. Third, some households frequently regret purchases and poorly smooth spending, but the small share of such households implies that this can account for only a small fraction of the average spending response to arrival.

Turning to the main correlates of spending response besides liquidity, both lack of financial planning and spending-type household are strongly correlated with liquidity and have limited predictive power beyond liquidity. This evidence is consistent with low liquidity directly causing high spending responses or with low liquidity being merely a symptom of these behaviors which themselves directly cause high spending responses. An example of the former is a model with financial frictions in which some households have high levels of impatience and face some costs of planning or optimization. Alternatively, the costs of optimization or behavioral characteristics could be central, causing some households to have low incomes, hold little liquidity, not use coupons or deals, fail to plan, and spend income when it arrives.

Further, low income is highly correlated both with spending responses and with liquidity, but also has significant predictive power beyond liquidity. If planning costs are negatively correlated with permanent income, then the Reis (2006) model of information processing frictions would generate these patterns. ${ }^{4}$

Finally, there is some limited evidence that both the propensity to regret purchases and the misunderstanding of payment amount is correlated with spending response. Both behaviors have little correlation with low liquidity and so, while they do not explain the majority of the spending response, they do suggest that some consumer behavior is driven by factors that do not operate through liquidity.

In interpreting these results, a number of caveats are in order. First, these estimates pertain to spending rather than consumption, and only over a one-month period that is precisely measured. Second, the measured relationship between spending response and characteristics would be distorted by different propensities to report spending caused by arrival across characteristics or by different propensities to increase spending caused by arrival on nonmeasured goods and services. Third, these results may or may not generalize to other domains of consumption smoothing or other populations. For example, incorrect expectations

\footnotetext{
${ }^{4}$ Provided that household react to cash flow due to not "absorbing and processing information" despite acquiring it. Similarly, Bernheim, Skinner and Weinberg (2001), Hurst (2003), Ameriks, Caplin and Leahy (2003), and Lusardi and Mitchell (2007) present evidence that differences in wealth across households are not well captured by behavior in the standard model even with financial frictions but are instead consistent with some features of models of behavior incorporating rules of thumb, mental accounts, problems with self-control, or an important role for planning. Similar evidence on saving behaviors is provided by Choi, Laibson and Madrian (2009) and Chetty et al. (2014).
} 
may be a more important determinant of spending responses for less publicized payments. Similarly, much larger or much smaller payments, may lead to different responses. However, (and not a caveat), Broda and Parker (2014) find no noticeable spending response when households learned about their payments.

\section{Sample of households: The Nielsen Consumer Panel}

The subjects for this study are a subset of the households in the 2008 NCP. The NCP is a panel survey of U.S. households in 52 metropolitan areas that measures demographic characteristics, annual income, and daily spending on household goods. Households report spending using barcode scanners and keypads at the conclusion of every shopping trip for household goods. ${ }^{5}$ Household goods include primarily grocery, drugstore and mass-merchandise sectors, and so the recorded expenditures primarily cover goods such as food and drug products, small appliances and electronic goods, and some mass merchandise products excluding apparel. Participants get newsletters and personalized tips and reminders via email and/or mail to upload spending information and to answer occasional surveys. For regularly uploading information, participants are entered in prize drawings and receive Nielsen points that can be accumulated and used to purchase prizes or 'gifts' from a catalogue.

Participants are surveyed when they initially join the survey and at the end of each subsequent calendar year about their demographic characteristics, and these answers are used as the demographic information for the following calendar year. Low performing households are dropped, and about 80 percent of Nielsen households are retained from year to year. Nielsen seeks to maintain a panel that is representative of the US population, and produces sampling weights that can be used to make the sample representative of the U.S. population along 10 demographic dimensions (including income). These weights are used throughout the analysis.

While the NCP is limited in the scope of spending that it covers, it has numerous benefits for the purpose at hand. First, while I primarily use information on total trip spending rather than the large amount of detail available on products (approximately 700,000 different goods are purchased at some point by household in the sample), the use of scanners and receipts in real time increases the accuracy of reported expenditures. The temporal precision allows analysis of weekly spending responses which increases the statistical power of the analysis given that the stimulus payments were randomized across weeks. Second, the NCP is relatively large: there are around 60,000 active households (of the roughly 120,000 households in the panel at any point in 2008) that meet the static reporting requirement used by Nielsen to define participating households for the period January to April 2008. Finally, Nielsen has in place a system to survey the households in the NCP. Nielsen typically uses these supplemental surveys to conduct marketing studies for corporate clients, conducting the surveys, analyzing the results, and delivering complete analyses to clients.

Christian Broda and I worked with Nielsen in March and April of 2008 to write and conduct a survey of the NCP households about both their characteristics and their receipt

\footnotetext{
${ }^{5}$ Households also scan individual items, enter a price if Nielsen does not already have it, and report whether they used any coupons or deals. For more details on the NCP see Broda and Weinstein (2010).
} 
of economic stimulus payments. The next section describes these payments, and the following section describes the supplemental survey. The data employed in this study are a combination of the responses to this supplemental survey, data licensed from Nielsen, and data available through the Kilts-Nielsen Data Center at The University of Chicago Booth School of Business. ${ }^{6}$

\section{The 2008 Economic Stimulus Payments}

Following Parker et al. (2013) and Broda and Parker (2014), I estimate the effect of liquidity on spending from the random variation in liquidity provided by the Economic Stimulus Act of 2008. The Act called for $\$ 100$ billion in economic stimulus payments to be disbursed to about 130 million eligible taxpayers. Because it was not administratively possible for the IRS to mail all stimulus checks or letters accompanying direct deposits at once, within each method of disbursement, the week in which the payment was disbursed was determined by the last two digits of the recipient's Social Security, digits which are effectively randomly assigned. ${ }^{7}$ For recipients that did not provide a personal bank routing number, the payments were mailed (using paper checks) in one of nine one-week periods ranging from the middle of May to the middle of July. ${ }^{8}$ The IRS sent a notification letter one week before the check was mailed. For recipients that provided the IRS with their personal bank routing number, the stimulus payments were disbursed electronically over three oneweek periods ranging from late April to the middle of May. ${ }^{9}$ The IRS mailed a statement to the household informing them about the deposit to arrive a few business days before the electronic transfer of funds. ${ }^{10}$ Table 1 shows the schedule of payment disbursements.

In terms of amount, each payment consisted of a basic payment and, if positive, an additional payment of $\$ 300$ per child that qualified for the child tax credit in 2007. The basic payment was generally the maximum of $\$ 300$ (\$600 for couples filing jointly) and a taxpayer's 2007 tax liability up to $\$ 600$ ( $\$ 1,200$ for couples). Households without tax liability received basic payments of $\$ 300$ ( $\$ 600$ for couples), so long as they had at least $\$ 3,000$ of qualifying 2007 income. The stimulus payment amount was reduced by five percent of the amount by which adjusted gross income exceeded a threshold of $\$ 75,000$ for individuals and $\$ 150,000$ for couples. Thus payments were not received by high-income households who earned enough to reduce their payments to zero nor by low-income households who had neither positive tax liability nor sufficient qualifying income.

\footnotetext{
${ }^{6}$ Data are available at: http://research.chicagobooth.edu/nielsen/.

${ }^{7}$ The last four digits of a Social Security number (SSN) are assigned sequentially to applicants within geographic areas (which determine the first three digits of the SSN) and a "group" (the middle two digits of the SSN).

${ }^{8}$ For late filers, if it was not possible to distribute the payment in the week proscribed by their SSN then it was distributed as soon after as possible.

${ }^{9}$ The payment was mailed for any tax return for which the IRS had only the tax preparer's routing number, as for example would occur as part of taking out a refund anticipation loan.

${ }^{10}$ Banks were notified a couple of days before the date of funds transfer, and some banks showed the amount on the beneficiary's bank account a day or more before the actual credit date. There were reports of banks crediting accounts on Friday April 25 for payments that were to be deposited on Monday April 28.
} 
TABle 1 -The Timing of the Economic Stimulus Payments

\begin{tabular}{|c|c|c|c|}
\hline \multicolumn{2}{|c|}{$\begin{array}{c}\text { Panel A: Payments by transfer of } \\
\text { electronic funds }\end{array}$} & \multicolumn{2}{|c|}{$\begin{array}{c}\text { Panel B: Payments by paper } \\
\text { check }\end{array}$} \\
\hline $\begin{array}{c}\text { Last two digits } \\
\text { of taxpayer } \\
\text { SSN }\end{array}$ & $\begin{array}{l}\text { Date by which } \\
\text { payment funds } \\
\text { deposited }\end{array}$ & $\begin{array}{c}\text { Last two digits } \\
\text { of taxpayer } \\
\text { SSN }\end{array}$ & $\begin{array}{c}\text { Date by which } \\
\text { payment check } \\
\text { in mail }\end{array}$ \\
\hline $00-20$ & May 2 & $00-09$ & May 16 \\
\hline $21-75$ & May 9 & $10-18$ & May 23 \\
\hline \multirow[t]{7}{*}{$76-99$} & May 16 & $19-25$ & May 30 \\
\hline & & $26-38$ & June 6 \\
\hline & & $39-51$ & June 13 \\
\hline & & $52-63$ & June 20 \\
\hline & & $64-75$ & June 27 \\
\hline & & $76-87$ & July 4 \\
\hline & & $88-99$ & July 11 \\
\hline
\end{tabular}

Source: Internal Revenue Service (2008).

\section{The NCP supplemental survey}

To measure the payments received by NCP households, a supplemental survey was administered to the households in the NCP. This survey consists of two parts, each to be answered by "the adult most knowledgeable about your household's income tax returns." The survey thus only measures the first payment received by a household, or, if more than one was received, the household was instructed to report the larger. Part I of the survey contains questions pertaining to the household's liquid assets and behaviors related to planning, spending, and self-control. Part II first describes the program of economic stimulus payments and then asks "Has your household received a tax rebate (stimulus payment) this year?" Households that respond positively, are subsequently asked about the amount and date of arrival of their stimulus payment, whether it was received by check or direct deposit, the extent to which the amount was expected, whether the household mostly saved or spent the stimulus payment, and the amount of spending across categories of goods.

The survey was fielded in multiple waves, with each wave following the standard procedures that Nielsen uses to survey the consumer panel households. For households with internet access and who were in communication with Nielsen by email the survey was administered in three waves in a web-based form, and for households without access and in 
contact with Nielsen by regular mail the survey was administered in only two waves in a paper/barcode scanner form, since the distribution time was slower and the preparation time greater. Repeated surveying was conditioned on earlier responses. ${ }^{11}$ The surveys covered the main period during which payments were distributed with random timing. A supplementary on-line appendix gives the timing of the surveys, the invitations and reminders, survey, response rates, and information about data access.

The repeated nature of the survey implies that the recall window for the payment is relatively short: one month for the email/web survey when it is first fielded and just over one and a half months for the mail/scanner survey when it first arrives. The survey was administered to all households meeting a Nielsen static reporting requirement for January through April 2008, which amounted to 46,620 households by email/web and 13,243 by mail/barcode scanner. For both types of survey, the response rates were 72 percent to the first wave, and 80 percent after all waves, giving 48,409 survey responses (of which some are invalid for various reasons).

To proceed, I drop all households from the analysis that: i) do not report receiving a payment (roughly 20 percent of the respondents); ii) do not report a date of payment receipt; iii) report not having received a payment in one survey and then later report receiving a payment prior to their response to the earlier in a later survey; iv) report receiving a payment after the date they submitted the survey; v) report receiving a payment by direct deposit (by mail) outside the period of the randomized disbursement by direct deposit (mail), and vi) do not report means of receipt but report receiving a payment outside both periods of randomized disbursement. ${ }^{12}$ These cuts reduce the sample to 28,937 households reporting receiving a total of over 26 million dollars in payments. These households are merged with the information on total spending on each trip taken by each household during 2008 from the KILTS NCP which includes only households that meet the Nielsen static reporting requirement for 2008. These data are collapsed down to total spending per week per household.

This sample selection is not random. It is however (presumably) uncorrelated with the randomization, and so creates no bias for estimation of the average treatment effect in the remaining sample. But it is important to note that given heterogeneity in treatment effect, non-random sample attrition may create bias if there are differences in treatment effects between households dropped from the sample and households that are included. It is also true that there is selection involved in which households are recruited and participate in the NCP survey.

Average (weighted) weekly spending in the baseline, static sample is $\$ 149$. The spending of households receiving payments by mail is $\$ 16$ less than that of households receiving a payment by direct deposit. The supplemental survey seems to provide an accurate mea-

\footnotetext{
${ }^{11}$ Households completing part I of the survey (household characteristics) in any wave were not asked Part I again. Households reporting payment information in Part II were not re-surveyed, so I measure only the first payment received by any household. Households that responded to the first question on Part II that they don't know whether they had received a stimulus payment, that they have not received one and "expect to," or respond that they "are unsure whether I will get any" do not proceed to Part II and are re-surveyed with Part II in a later wave (if there is one). Finally, households that respond "No, and I am definitely not getting one" do not proceed and are not re-surveyed.

${ }^{12}$ I allow a two day grace period for reporting relative to survey submit dates, and a seven day grace period for misreporting relative to the period of randomization. I do not adjust the reported date of receipt in either case.
} 
sure of payment and payment receipt. The average payment conditional on receiving one is $\$ 898$. Households receiving payments by direct deposit on average have higher payments by about $\$ 190$, which is reasonably consistent with their having on average 0.4 members more in these households. ${ }^{13}$ As was true for the actual disbursements, most reported payments are clustered at multiple of $\$ 300 .{ }^{14}$ These features of the distributions line up well with those in similar surveys conducted by the SIPP and the CEX (see Parker et al. (2013)). More details and tables of summary statistics are provided in the on-line appendix.

\section{Estimation methodology}

The question of interest is which households respond more and less strongly to payment arrival. Thus, rather than estimate the dollars spent on arrival or the percent increase in spending, I measure the spending response in terms of the share of payment spent. Specifically, I use the following specification to examine the average impact of the receipt of a payment on spending for household $i$ with characteristic $j$ in week $t$ receiving a payment by method $m$ :

$$
C_{i, t}=\mu_{i}+\sum_{s=-L}^{S} \beta_{s, j} E S P_{i, t+s}+\tau_{m, j, t}+\eta_{i, t}
$$

where $C_{i, t}$ is the dollar amount of NCP spending by household $i$ in week $t ; \mu_{i}$ is a householdspecific intercept that captures differences in the average level of spending across households; $E S P_{i, t}$ is zero when a payment is not received and is the average amount received for that type of household by that method of disbursement (mail or direct deposit) when the household gets their payment; $\tau_{m, j, t}$ is a set of (regression coefficients on) indicator variables for every week in the sample for each type of household for each method of disbursement; finally $\eta_{i, t}$ captures all expenditures unexplained by the previous factors. The parameters of interest are the $\beta_{s, j}$ which importantly differ by type of household $j$. The $\beta_{s, j}$ measure, for each type of household, the marginal propensity to spend out of a payment before arrival (up to $L$ leads), the week of arrival, and following arrival (up to the largest possible lag, $S$ ). These effects are identified by the restriction that $\beta_{s, j}=0$ for all $s,<-L$.

Because there are time effects interacted with type $j$ and means of receipt, differences in in the impact of aggregate changes or difference in seasonal spending between recipients with different characteristics or means of disbursement do not bias the estimated $\beta_{s, j}$. That said, this specification is demanding of the data, so I also report results with a complete set of time dummies interacted only with household type and not with means of receipt (and where average payment amount for $E S P_{i, t}$ is measured separately over $j$ but not $m$ ).

Finally, identification of the key parameters of interest for a type $j$ does not require that

\footnotetext{
${ }^{13}$ Recall that each additional child eligible for the child tax credit leads to $\$ 300$ larger payment, while a married couple receives $\$ 600$ more than the equivalent family with an unmarried head.

${ }^{14}$ Households in the mail survey were prompted by the example of $\$ 600$ as part of reminding them how to enter a dollar amount on their barcode scanner. There was no amount prompt in the on-line survey.
} 
households are similar, or unselected, across types. Consistency requires that the variation in $E S P_{i, t}$ be uncorrelated with all other factors that might influence household expenditure besides the receipt-driven variation of interest. Selection into type $j-$ or more generally correlation of type and average treatment effect - does not bias estimates of average effects within type. In fact, differences in average treatment effect are the main issues of interest. But it is important to note that selection into the NCP and/or selective attrition out of our sample ex ante or over time could bias population inference of differences in average treatment effects across household types if correlated with treatment effect. For example, suppose that the extent of consumption smoothing were uncorrelated with wealth across households in the population. If low wealth households that smooth consumption well did not respond to our survey and everyone else did, then we would observe in our sample that low wealth households smooth consumption more poorly than high wealth households. But this would be true only for our sample and not the population.

In estimation, standard errors are adjusted to allow for arbitrary heteroskedasticity and within-household serial correlations.

\section{The baseline result: the average response of spending and the importance of liquidity}

Before analyzing differences in responses across household types, I present the existing results (e.g., Broda and Parker, 2014) that, first, there is a significant increase in spending caused by the receipt of a payment on average across all households (only one type $j$ ), and, second, the majority of this increase is due to households with low levels of liquid wealth. Table 2 displays results from estimation of equation (1) for two specifications each with three leads of ESP: one that uses all variation in timing of receipt (the first three columns; only one category of $m$ ), and one that treats the two different methods of disbursement as two separate experiments (the second three columns).

According to both specifications, households on average spend one and a half percent of the payment the week of arrival (first row, first and fourth columns). This response is highly statistically significant. And the cumulative response over four weeks is roughly three and a half percent of the payment, also highly statistically significant.

These small propensities to spend do not imply small spending responses overall because these measures include only spending on goods covered by the NCP data. Parker et al. (2013) look at all spending categories in the CEX and find that the majority of the payments are spent during the three-month period that includes arrival, and that the categories of goods that comprise the majority of the spending in the NCP are those that respond the least (e.g. food at home).

As shown in Table D in the unpublished appendix, there is no rise in spending in the three weeks prior to the arrival of the payment. All coefficients after the fourth week are statistically insignificant and economically small. As a result, for the balance of the paper, I focus on consumption smoothing on arrival and over the following four weeks.

These results are robust to a number of alternative specifications. In a specification that replaces $E S P$ with a categorical variable indicating arrival, households on average increase their spending by $\$ 13$ the week of arrival and by $\$ 30$ cumulatively over four weeks. In a specification that additionally replaces the dependent variable with spending relative to the 
TAble 2-Spending Propensities for all Households AND by Liquidity

\begin{tabular}{|c|c|c|c|c|c|c|}
\hline & \multicolumn{3}{|c|}{$\begin{array}{c}\text { Using all variation in time of } \\
\text { receipt }\end{array}$} & \multicolumn{3}{|c|}{$\begin{array}{l}\text { Using only variation in timing } \\
\text { within each method of receipt }\end{array}$} \\
\hline & \multirow[t]{2}{*}{$\begin{array}{c}\text { All } \\
\text { households }\end{array}$} & \multicolumn{2}{|c|}{$\begin{array}{l}\text { At least two months } \\
\text { available income in } \\
\text { liquid wealth? }\end{array}$} & \multirow[t]{2}{*}{$\begin{array}{c}\text { All } \\
\text { households }\end{array}$} & \multicolumn{2}{|c|}{$\begin{array}{c}\text { At least two months } \\
\text { available income in } \\
\text { liquid wealth? }\end{array}$} \\
\hline & & Yes & No & & Yes & No \\
\hline $\begin{array}{l}\text { Contemporaneous } \\
\text { week }\end{array}$ & $\begin{array}{c}1.49 \\
(0.25)\end{array}$ & $\begin{array}{c}0.63 \\
(0.29)\end{array}$ & $\begin{array}{c}2.78 \\
(0.39)\end{array}$ & $\begin{array}{c}1.45 \\
(0.29)\end{array}$ & $\begin{array}{c}0.66 \\
(0.30)\end{array}$ & $\begin{array}{c}2.53 \\
(0.42)\end{array}$ \\
\hline $\begin{array}{l}\text { t-stat of } \\
\text { 'Yes' equal 'No' }\end{array}$ & \multicolumn{3}{|c|}{4.47} & & \multicolumn{2}{|c|}{3.64} \\
\hline $\begin{array}{l}\text { Four week } \\
\text { cumulative increase }\end{array}$ & $\begin{array}{c}3.70 \\
(0.70)\end{array}$ & $\begin{array}{c}2.04 \\
(0.74)\end{array}$ & $\begin{array}{c}6.57 \\
(1.01)\end{array}$ & $\begin{array}{c}3.31 \\
(0.46)\end{array}$ & $\begin{array}{c}2.08 \\
(1.03)\end{array}$ & $\begin{array}{c}4.87 \\
(1.36)\end{array}$ \\
\hline $\begin{array}{l}\text { t-stat of } \\
\text { 'Yes' equal 'No' }\end{array}$ & \multicolumn{3}{|c|}{3.63} & & \multicolumn{2}{|c|}{1.64} \\
\hline $\begin{array}{l}\text { Number of } \\
\text { households }\end{array}$ & 21,386 & 13,685 & 7,656 & 21,320 & 13,654 & 7,621 \\
\hline
\end{tabular}

Note: Standard errors in parentheses. Table reports the propensity to consume NCP goods out of a payment in percent. The regressions in the first triplet of columns include fixed effects for each week in the sample and in the second triplet of columns include fixed effects for each week for each means of receipt. All regressions include household fixed effects and are weighted by the NCP projection factor for 2008. Each sample includes only households that report receipt during the period of the experimental variation, sufficient ESP information for that specification, and meet the standard NCP static reporting requirement for the year. Calculated based on data from The Nielsen Company (US) LLC and provided by the Marketing Data Center at the University of Chicago Booth School of Business.

first 12 weeks of the year households increase their spending by just under 10 percent of average weekly spending the week of arrival and roughly 5 percent of spending over four weeks. ${ }^{15}$ Given average weekly spending of $\$ 149$ and an average payment of $\$ 898$, these numbers are consistent with columns 1 and 4 in Table 2.

If the spending response were the same across households, then cross-sectional information would be useless for evaluating models of lack of consumption smoothing. Instead, there is significant heterogeneity in spending response across households correlated with liquidity (e.g., Zeldes (1989a); Johnson, Parker and Souleles (2006); Agarwal, Liu and Souleles (2007); and in this dataset, Broda and Parker (2014)). The investigation of liquid-

\footnotetext{
${ }^{15}$ These results are also displayed in Appendix Table D. Additionally, similar patterns emerge when restricting to households reporting spending in at least half the weeks or in every week, and when trimming the top and bottom 1 percent of spending. Similar percentage changes and spending effects relative to average dollar spending are found using as a measure of weekly spending the more volatile and smaller measure of spending constructed as the sum of all individual items purchased instead of the sum of all total trip spending and using households that do not meet the Nielsen static reporting requirement for the year.
} 
ity is motivated by models of consumption smoothing with financial frictions. If a household either is unable to borrow due to a binding liquidity constraint or does not want to borrow due to a high elasticity of precautionary saving with respect to cash on hand, then low current or recent income can indicate that a household has a higher propensity to spend income on arrival. The main prediction is that households with low levels of liquid wealth fail to smooth consumption.

To measure liquidity, Part I of the supplemental survey contains the question "In case of an unexpected decline in income or increase in expenses, do you have at least two months of income available in cash, bank accounts, or easily accessible funds?" and the respondent can answer yes or no. This measurement instrument is motivated by the canonical buffer-stock model (e.g., Carroll, 1997) which uses scale-invariant preferences and in which liquidity is naturally measured as available funds relative to the permanent component of income.

Columns 3 and 6 of Table 2 show that households with low liquidity, which make up 36 percent of the sample, spend 2.5 to 2.8 percent of the payment the week of arrival and 4.9 to 6.6 percent the four weeks of and following arrival. Households with sufficient liquid wealth still exhibit a statistically significant increase in spending in response to arrival, but they spend only at one fourth the rate of households with insufficient wealth the week the payment arrives, and one half to one third the rate over the four weeks of and following arrival. ${ }^{16}$ This finding is consistent with previous research and consistent with the presence of liquidity constraints or incomplete financial markets: lack of consumption smoothing is concentrated among households with low liquidity.

\section{Differences in spending responses and models of spending responses}

The significant heterogeneity in the spending response implies that one can test models of consumer behavior by evaluating their ability to explain cross-sectional differences in spending responses. If a model of consumer behavior cannot generate variation in spending responses across households, or if the determinants or indicators of this variation show no variation in the data, then this model is inconsistent with the finding that some households smooth spending well and some poorly. Further, given the large amount of heterogeneity associated with liquid wealth, any such determinant that is uncorrelated with liquid wealth will miss a large amount of variation in behavior and so is unlikely to be the main reason that households fail to smooth consumption.

Plausible theories then must predict variation in consumption smoothing along an observable characteristic that is correlated with liquidity. Such a relationship raises the question of whether this characteristic causes low liquidity or whether this characteristic is caused by or merely correlated with low liquidity. This paper does not observe plausibly exogenous variation in the characteristic or liquidity, and so cannot distinguish the direction of causation.

\footnotetext{
${ }^{16}$ Despite the additional set of time dummies interacted with method of receipt in these subsample regressions, the sample weighted average of the spending increases are almost exactly equal to the average spending increase.
} 


\section{A. Heterogeneity in consumption smoothing: transitory state or persistent characteristic?}

Perhaps the leading model that incorporates lack of consumption smoothing is caused by a series of poor income shocks, as in the parametrization of models of such as Zeldes (1989b), Deaton (1991), and Carroll (1997), or by a transitory low level of liquid assets due to fixed costs of portfolio adjustment, as in the model of Kaplan and Violante (2014). An alternative is that persistent behavioral traits cause low liquid wealth and, either directly or indirectly through low liquidity, cause spending responses. This behavioral trait could be impatience, but it could also be due to nonlinearities in budget constraints such as caused by means tested benefit programs.

This subsection shows that lack of consumption smoothing is a characteristic that lasts years and is not due to temporarily low or high liquidity that might arise for example from management of illiquid wealth, year-end bonuses, tax refunds, moderate shocks to spending needs, or insured, short-term job loss. I show that, while measured only crudely, recent income growth and consumption smoothing are unrelated so that transitory income changes play no measurable role in spending responses to the arrival of payments. The level of income in 2008 however has a strong correlation with both liquidity and consumption smoothing. Households with low current income smooth consumption poorly while households with high current income smooth consumption well. But a similar relationship exists for income in 2007 and, even more strikingly for income in 2006, two years prior to the payments. This pattern also holds for households with sufficient liquidity and for households with low liquidity. Thus, lack of consumption smoothing appears to be a persistent characteristic related to low permanent income, and not primarily driven by transitory and moderate income shocks or costs of accessing illiquid wealth and temporary low liquidity. Finally, there is evidence that lack of consumption smoothing is not purely due to low liquidity. Low income in 2006 predicts a larger spending response even conditional on liquidity.

Households in the NCP are surveyed about annual income at the end of each calendar year about the previous calendar year and this information is reported in the subsequent year's panel. Income is reported in 19 income ranges. The ranges are each less than or equal to $\$ 5,000$ for incomes less than $\$ 50,000$, then rise through $\$ 10,000$ and then $\$ 25,000$ ranges until the highest two ranges covering an income range or $\$ 150,000$ to $\$ 200,000$ and $\$ 200,000$ and above. A household is defined as having an income increase if it reports moving to a higher range and a decrease if it reports moving to a lower range. Panel $\mathrm{A}$ in Table 3 shows spending responses for households whose income moves to a lower range, stays in the same range, and moves to a higher range from 2007 to 2008, the year of the payment program. There is no evidence of any differential spending response across categories of income growth. Panel B repeats this exercise for income changes from 2006 to 2007. In Panel B, there is no evidence that households that have had declines in income spend more of their payments on receipt than households whose incomes have stayed in the same range or than those whose incomes have increased. In fact, there is some evidence of the reverse; household spending responses are increasing in income growth from 2006 to 2007. While measurement is not precise, these results on income growth are inconsistent with the view that the high spending response of low income households is due to temporarily low 
TABle 3-SPEnding Responses By Income Growth AND Income Group

\begin{tabular}{|c|c|c|c|c|c|c|}
\hline \multirow[b]{2}{*}{$\begin{array}{l}\text { Panels } A \text { and } B: \\
\text { Income growth }\end{array}$} & \multicolumn{3}{|c|}{ Using all variation in time of receipt } & \multicolumn{3}{|c|}{$\begin{array}{l}\text { Using only variation in timing } \\
\text { within each method of receipt }\end{array}$} \\
\hline & $\begin{array}{l}\text { To lower } \\
\text { category }\end{array}$ & $\begin{array}{c}\text { Same } \\
\text { category }\end{array}$ & $\begin{array}{l}\text { To higher } \\
\text { category }\end{array}$ & $\begin{array}{l}\text { To lower } \\
\text { category }\end{array}$ & $\begin{array}{c}\text { Same } \\
\text { category }\end{array}$ & $\begin{array}{l}\text { To higher } \\
\text { category }\end{array}$ \\
\hline $\begin{array}{l}\text { Contemporaneous } \\
\text { week }\end{array}$ & $\begin{array}{l}1.35 \\
(0.57)\end{array}$ & $\begin{array}{l}\text { Pane } \\
0.99 \\
(0.39)\end{array}$ & $\begin{array}{c}\text { A: Income gl } \\
1.70 \\
(0.61)\end{array}$ & $\begin{array}{c}\text { wth } 2007 \text { tc } \\
0.85 \\
(0.64)\end{array}$ & $\begin{array}{c}\frac{2008}{0.90} \\
(0.42)\end{array}$ & $\begin{array}{l}1.29 \\
(0.67)\end{array}$ \\
\hline $\begin{array}{l}\text { Four week } \\
\text { cumulative increase }\end{array}$ & $\begin{array}{l}4.18 \\
(1.55)\end{array}$ & $\begin{array}{l}2.45 \\
(1.05)\end{array}$ & $\begin{array}{c}4.57 \\
(1.61)\end{array}$ & $\begin{array}{l}1.35 \\
(2.06)\end{array}$ & $\begin{array}{c}1.84 \\
(1.46)\end{array}$ & $\begin{array}{l}1.80 \\
(2.11)\end{array}$ \\
\hline \multirow{2}{*}{$\begin{array}{l}\text { Number of } \\
\text { households }\end{array}$} & 3,416 & 7,719 & 3,051 & 3,405 & 7,696 & 3,042 \\
\hline & \multicolumn{6}{|c|}{ Panel B: Income growth 2006 to 2007} \\
\hline $\begin{array}{l}\text { Contemporaneous } \\
\text { week }\end{array}$ & $\begin{array}{l}1.19 \\
(0.65)\end{array}$ & $\begin{array}{l}1.28 \\
(0.32)\end{array}$ & $\begin{array}{l}1.94 \\
(0.61)\end{array}$ & $\begin{array}{c}0.88 \\
(0.64)\end{array}$ & $\begin{array}{l}1.10 \\
(0.35)\end{array}$ & $\begin{array}{l}1.89 \\
(0.65)\end{array}$ \\
\hline $\begin{array}{l}\text { Four week } \\
\text { cumulative increase }\end{array}$ & $\begin{array}{l}2.20 \\
(1.61)\end{array}$ & $\begin{array}{l}4.01 \\
(0.86)\end{array}$ & $\begin{array}{l}5.19 \\
(1.57)\end{array}$ & $\begin{array}{l}0.12 \\
(2.08)\end{array}$ & $\begin{array}{l}3.28 \\
(1.19)\end{array}$ & $\begin{array}{l}4.23 \\
(2.26)\end{array}$ \\
\hline $\begin{array}{l}\text { Number of } \\
\text { households }\end{array}$ & 3,142 & 10,051 & 4,055 & 3,133 & 10,023 & 4,042 \\
\hline $\begin{array}{c}\text { Panels } C, D \text { and } E: \\
\text { Income levels }\end{array}$ & $\begin{array}{c}\text { income }< \\
\$ 35,000\end{array}$ & $\begin{array}{c}\$ 35,000 \leq \\
\text { income } \\
<\$ 70,000\end{array}$ & $\begin{array}{l}\$ 70,000 \leq \\
\text { income }\end{array}$ & $\begin{array}{c}\text { income }< \\
\$ 35,000\end{array}$ & $\begin{array}{c}\$ 35,000 \leq \\
\text { income } \\
<\$ 70,000\end{array}$ & $\begin{array}{l}\$ 70,000 \leq \\
\text { income }\end{array}$ \\
\hline $\begin{array}{l}\text { Contemporaneous } \\
\text { week }\end{array}$ & $\begin{array}{l}2.46 \\
(0.58)\end{array}$ & $\begin{array}{l}1.40 \\
(0.45)\end{array}$ & $\begin{array}{c}\text { Panel C: } 2 \\
0.21 \\
(0.49)\end{array}$ & $\begin{array}{c}8 \text { Income } \\
2.06 \\
(0.64)\end{array}$ & $\begin{array}{c}0.87 \\
(0.49)\end{array}$ & $\begin{array}{c}0.39 \\
(0.50)\end{array}$ \\
\hline $\begin{array}{l}\text { Four week } \\
\text { cumulative increase }\end{array}$ & $\begin{array}{l}3.78 \\
(1.64)\end{array}$ & $\begin{array}{l}4.01 \\
(1.16)\end{array}$ & $\begin{array}{c}2.20 \\
(1.33)\end{array}$ & $\begin{array}{l}2.68 \\
(2.02)\end{array}$ & $\begin{array}{c}1.07 \\
(1.46)\end{array}$ & $\begin{array}{c}1.98 \\
(1.95)\end{array}$ \\
\hline $\begin{array}{l}\text { Number of } \\
\text { households }\end{array}$ & \multicolumn{6}{|c|}{ Panel D: 2007 Income } \\
\hline $\begin{array}{l}\text { Contemporaneous } \\
\text { times }\end{array}$ & $\begin{array}{l}2.56 \\
(0.55)\end{array}$ & $\begin{array}{c}1.44 \\
(0.40)\end{array}$ & $\begin{array}{c}0.71 \\
(0.44)\end{array}$ & $\begin{array}{c}2.39 \\
(0.57)\end{array}$ & $\begin{array}{l}1.11 \\
(0.44)\end{array}$ & $\begin{array}{l}0.65 \\
(0.46)\end{array}$ \\
\hline $\begin{array}{l}\text { Four week } \\
\text { cumulative increase }\end{array}$ & $\begin{array}{l}5.35 \\
(1.44)\end{array}$ & $\begin{array}{c}3.97 \\
(1.05)\end{array}$ & $\begin{array}{c}3.17 \\
(1.19)\end{array}$ & $\begin{array}{l}4.85 \\
(1.81)\end{array}$ & $\begin{array}{c}3.02 \\
(1.44)\end{array}$ & $\begin{array}{c}1.73 \\
(1.71)\end{array}$ \\
\hline $\begin{array}{l}\text { Number of } \\
\text { households }\end{array}$ & 6,067 & 6,398 & 4,783 & 6,049 & 6,377 & 4,772 \\
\hline $\begin{array}{l}\text { Contemporaneous } \\
\text { week }\end{array}$ & $\begin{array}{l}3.13 \\
(0.57)\end{array}$ & $\begin{array}{c}1.41 \\
(0.34)\end{array}$ & $\begin{array}{c}\text { Panel E: } 20 \\
0.56 \\
(0.37)\end{array}$ & $\frac{6 \text { Income }}{3.09}$ & $\begin{array}{l}1.15 \\
(0.37)\end{array}$ & $\begin{array}{c}0.59 \\
(0.39)\end{array}$ \\
\hline $\begin{array}{l}\text { Four week } \\
\text { cumulative increase }\end{array}$ & $\begin{array}{c}6.99 \\
(1.33)\end{array}$ & $\begin{array}{c}3.44 \\
(0.90)\end{array}$ & $\begin{array}{c}1.99 \\
(1.02)\end{array}$ & $\begin{array}{c}8.13 \\
(1.73)\end{array}$ & $\begin{array}{l}2.16 \\
(1.20)\end{array}$ & $\begin{array}{l}1.10 \\
(1.42)\end{array}$ \\
\hline $\begin{array}{l}\text { Number of } \\
\text { households }\end{array}$ & 7,495 & 7,783 & 6,063 & 7,466 & 7,761 & 6,048 \\
\hline
\end{tabular}

Note: Standard errors in parentheses. The table reports the propensity to consume NCP goods out of a payment in percent. The regressions in the first triplet of columns include fixed effects for each week in the sample and in the second triplet of columns include fixed effects for each week for each means of receipt. All regressions include household fixed effects and are weighted by the NCP projection factor for 2008. Each sample includes only households that report receipt during the period of the experimental variation, sufficient ESP information for that specification, and meet the standard NCP static reporting requirement for the year. Calculated based on data from The Nielsen Company (US) LLC and provided by the Marketing Data Center at the University of Chicago Booth School of Business. 
income. ${ }^{17}$

Panel C of Table 3 splits households into three roughly equal groups according to 2008 income. ${ }^{18}$ The bottom 36 percent of households by 2008 income - those with annual labor incomes of less than $\$ 35,000$ - spend at roughly double the rate of the other income groups. The group with highest 2008 income does not consume a statistically significant fraction of the payment in either specification or at either horizon. This is inconsistent with the textbook model of liquidity constraints (or precautionary saving), in which a household's temporarily low income leads them to violate consumption smoothing because they are unable to borrow against (or insure) future labor income. This same pattern is evident in Panel D in which households are split according to their incomes in 2007.

Most strikingly, the same pattern is observed in Panel E using income in 2006. Low income in 2006 indicates poor consumption smoothing in 2008, and high income in 2006 indicates good consumption smoothing in 2008. In fact, low income in 2006 is as good as, if not better than, contemporaneous liquidity (Table 2) at separating the households who spent from those who did not. This evidence is at odds with models in which either low transitory income or portfolio management cause quite temporary low liquidity and large spending responses for some households, such as the textbook, scale-invariant models of buffer-stock behavior. Rather, according to this evidence, households that have low income over several years are poor at smoothing consumption.

How does income interact with liquidity in explaining spending responses? Table 4 shows how household responses differ by both income and liquidity. Panels A and B show that 2008 income level is correlated with liquidity: 45 percent of households with low liquidity have low income in 2008 while 31 percent of households with sufficient liquidity have low income. Panel C and D show that this correlation is just as strong between income in 2006 and liquidity in 2008.

Conditional on sufficient liquidity, households with low income in 2006 have significant spending responses (Panel C) while households with high incomes do not. And conditional on low liquidity (Panel D), there are statistically significant differences in the size of the spending response at four weeks between households with high incomes in 2006 and those with low incomes. In sum, there is a lot of variation in spending response in 2008 across households explained by household income in 2006, both unconditionally (Table 3 panel E) and conditional on current liquidity (Table 4 Panels C and D).

\section{B. Beliefs: are spending response due to households that are surprised by their payments?}

This subsection shows that the households who spent their payments when they arrived did not do so because they were not expecting their payments. Most households expected the payments, there are significant spending responses for those who were expecting their payments, and households that are positively surprised by their payments spend similarly to those that are negatively surprised. The responses of these two groups of surprised households do provide some weak evidence linking understanding of the stimulus program and

\footnotetext{
${ }^{17}$ This lack of correlation with spending responses is also found with a measure of temporarily low income based on 2007 income relative to surrounding years.

${ }^{18}$ These ranges/choices follow the industry standard, see Zeldes (1989a), Jappelli, Pischke and Souleles (1998), Jappelli (1990), and Souleles (1999).
} 
TABLE 4-SPENDING RESPONSES By LIQUidity AND INCOME LEVEL

\begin{tabular}{|c|c|c|c|c|c|c|}
\hline & \multicolumn{3}{|c|}{$\begin{array}{l}\text { Using all variation in time of } \\
\text { receipt }\end{array}$} & \multicolumn{3}{|c|}{$\begin{array}{l}\text { Using only variation in timing } \\
\text { within each method of receipt }\end{array}$} \\
\hline & $\begin{array}{r}\text { income }< \\
\$ 35,000\end{array}$ & $\begin{array}{c}\$ 35,000 \leq \\
\text { income } \\
<\$ 70,000\end{array}$ & $\begin{array}{l}\$ 70,000 \leq \\
\text { income }\end{array}$ & $\begin{array}{r}\text { income }< \\
\$ 35,000\end{array}$ & $\begin{array}{l}\$ 35,000 \leq \\
\text { income } \\
<\$ 70,000\end{array}$ & $\begin{array}{l}\$ 70,000 \leq \\
\text { income }\end{array}$ \\
\hline Contemporaneous week & $\begin{array}{l}\text { Panel A: } \\
0.91 \\
(0.76)\end{array}$ & $\begin{array}{c}\text { Households } \\
0.62 \\
(0.50)\end{array}$ & $\begin{array}{c}\text { with suffici } \\
-0.06 \\
(0.55)\end{array}$ & 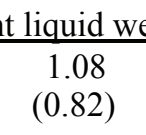 & $\frac{\text { alth, by } 2008}{-0.03}$ & $\frac{8 \text { income }}{0.17}$ \\
\hline $\begin{array}{l}\text { Four week } \\
\text { cumulative increase }\end{array}$ & $\begin{array}{l}-0.17 \\
1.92\end{array}$ & $\begin{array}{c}3.55 \\
(1.44)\end{array}$ & $\begin{array}{c}0.41 \\
(1.51)\end{array}$ & $\begin{array}{c}0.18 \\
(2.51)\end{array}$ & $\begin{array}{c}0.89 \\
(1.76)\end{array}$ & $\begin{array}{c}0.66 \\
(2.26)\end{array}$ \\
\hline Number of households & 3,068 & 3,762 & 2,964 & 3,055 & 3,754 & 2,962 \\
\hline Contemporaneous week & $\begin{array}{c}\text { Panel } \\
4.23 \\
(0.90)\end{array}$ & 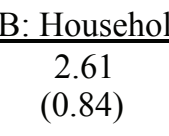 & 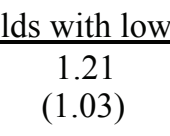 & 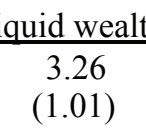 & $\frac{\text { a, by } 2008 \text { in }}{2.23}$ & $\begin{array}{c}\frac{\text { ncome }}{1.20} \\
(1.08)\end{array}$ \\
\hline $\begin{array}{l}\text { Four week } \\
\text { cumulative increase }\end{array}$ & $\begin{array}{c}8.41 \\
(2.76)\end{array}$ & $\begin{array}{c}4.74 \\
(1.99)\end{array}$ & $\begin{array}{c}8.31 \\
(2.86)\end{array}$ & $\begin{array}{c}5.77 \\
(3.29)\end{array}$ & $\begin{array}{c}1.10 \\
(2.56)\end{array}$ & $\begin{array}{c}6.44 \\
(3.66)\end{array}$ \\
\hline Number of households & 1,989 & 1,541 & 862 & 1,980 & 1,535 & 857 \\
\hline Contemporaneous week & $\begin{array}{l}\text { Panel C: } \\
2.33 \\
(0.85)\end{array}$ & $\begin{array}{c}\text { Households } \\
0.44 \\
(0.41)\end{array}$ & $\begin{array}{c}\text { with suffici } \\
0.06 \\
(0.42)\end{array}$ & 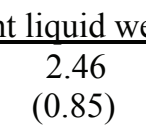 & $\frac{\text { alth, by } 200}{0.24}$ & $\frac{6 \text { income }}{0.21}$ \\
\hline $\begin{array}{l}\text { Four week } \\
\text { cumulative increase }\end{array}$ & $\begin{array}{c}3.79 \\
(1.70)\end{array}$ & $\begin{array}{c}2.27 \\
(1.16)\end{array}$ & $\begin{array}{c}1.04 \\
(1.19)\end{array}$ & $\begin{array}{c}5.45 \\
(2.33)\end{array}$ & $\begin{array}{c}1.97 \\
(1.61)\end{array}$ & $\begin{array}{c}0.79 \\
(1.60)\end{array}$ \\
\hline Number of households & 4,147 & 5,047 & 4,491 & 4,134 & 5,036 & 4,484 \\
\hline Contemporaneous week & $\begin{array}{l}\frac{\text { Panel }}{3.79} \\
(0.76)\end{array}$ & 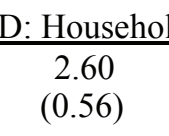 & 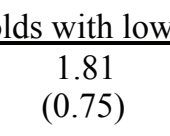 & $\begin{array}{c}\text { iquid weal } \\
3.69 \\
(0.81)\end{array}$ & $\frac{h, \text { by } 2006 \text { ir }}{2.23}$ & $\begin{array}{c}\frac{\text { ncome }}{1.52} \\
(0.81)\end{array}$ \\
\hline $\begin{array}{l}\text { Four week } \\
\text { cumulative increase }\end{array}$ & $\begin{array}{c}9.91 \\
(2.01)\end{array}$ & $\begin{array}{c}5.02 \\
(1.40)\end{array}$ & $\begin{array}{c}4.45 \\
(2.01)\end{array}$ & $\begin{array}{l}10.40 \\
(2.53)\end{array}$ & $\begin{array}{c}2.22 \\
(1.79)\end{array}$ & $\begin{array}{c}1.53 \\
(3.06)\end{array}$ \\
\hline Number of households & 3,348 & 2,736 & 1,572 & 3,332 & 2,725 & 1,564 \\
\hline
\end{tabular}

Note: Standard errors in parentheses. The table reports the propensity to consume NCP goods out of an ESP in percent. The regressions in the first triplet of columns include fixed effects for each week in the sample and in the second triplet of columns include fixed effects for each week for each means of receipt. All regressions include household fixed effects and are weighted by the NCP projection factor for 2008. Each sample includes only households that report receipt during the period of the experimental variation, sufficient ESP information for that specification, and meet the standard NCP static reporting requirement for the year. Calculated based on data from The Nielsen Company (US) LLC and provided by the Marketing Data Center at the University of Chicago Booth School of Business. 
consumption smoothing: in one of two specifications spending response are greater for the households that incorrectly understood the payments by not expecting the payment, underestimating the amount, or (primarily) overestimating the amount.

One reason that the arrival of a pre-announced payment might cause an increase in spending is if some households are surprised by the arrival of the payment despite available information about the payment. Motivated in part by the findings of excess sensitivity, recent modeling of human behavior has considered the costs of gathering and processing information and how economizing on these costs might alter the predictions of the canonical model of consumption and saving (e.g., Caballero, 1995; Reis, 2006; Sims, 2003).

While these models need not imply strong spending response to receipt, Reis (2006) shows that households with large costs of optimization choose to be 'inattentive savers' who follow a saving plan and optimally let consumption track income. While these models also have implications for the relationship between measures of planning and spending responses, this subsection assesses the role of expectations in the spending response. The supplemental survey asked households who reported that they received a payment: "Was this about the amount your household was expecting?" Households were given the following answers to choose from: 'No, and we were surprised to get any rebate at all,' 'No, and it was less than we were expecting,' 'No, and it was more than we were expecting,' 'Yes, and we've known the approximate amount since February,' 'Yes, and we've known the approximate amount since March,' 'Yes, and we've known the approximate amount since April,' 'Yes, but we only learned about it recently,' and 'Not sure/don't know.'

Panel A of Table 5 contains the results for three groups of households and shows four main results. First, the last row of Panel A shows that most households expected the payment when it arrived. Only 12 percent of households were positively surprised (columns 2 and 5); 5 percent of households were surprised by the arrival and 7 percent found that it was more than they were expecting. Thirteen percent of households found that their payment was less than they expected (columns 3 and 6). Second, even those households who had been expecting the payment in the correct amount had significant spending response to the arrival on impact and cumulatively over 4 weeks (columns 1 and 4). Third, while few households were positively surprised by the payment, there is some statistically weak evidence that this led to a higher propensity to spend on impact but no consistent evidence of more spending over four weeks. ${ }^{19}$

Finally, not only is there no decline in spending for households who received payments that were less than they were expecting, but point estimates suggest that these households actually spent at higher rates than the average household. One can reject the equality of the contemporaneous spending response between households who are expecting the payment (columns 1) and those who are negatively surprised (column 3) (t-statistic 2.08). This is not the case for the four week response (t-statistic $=1.47$ ) nor at either horizon in the second set of columns, in which the responses across groups are more similar.

Panels B and C split households by liquidity. The mistake of expecting a larger than actual payment is more prevalent among households with insufficient funds: 18 percent of households with low liquid wealth are negatively surprised by the amount of their pay-

\footnotetext{
${ }^{19}$ The propensity to spend is larger for households surprised by the payment in the first triplet of columns, but not in the second triplet in which the distribution by mail and by direct deposit are treated as separate experiments.
} 
TABLE 5-SPENDing RESPONSES By LIQUidity AND INCOME LEVEL

\begin{tabular}{|c|c|c|c|c|c|c|}
\hline \multirow{3}{*}{$\begin{array}{c}\text { Was this about } \\
\text { the amount your } \\
\text { household was } \\
\text { expecting? }\end{array}$} & \multicolumn{3}{|c|}{ Using all variation in time of receipt } & \multicolumn{3}{|c|}{$\begin{array}{c}\text { Using only variation in timing withir } \\
\text { each method of receipt }\end{array}$} \\
\hline & $\begin{array}{c}\text { Yes, known } \\
\text { since Feb, } \\
\text { March, or } \\
\text { Apr. } \\
\end{array}$ & $\begin{array}{l}\text { Learned } \\
\text { more } \\
\text { recently or } \\
\text { positively } \\
\text { surprised }\end{array}$ & $\begin{array}{c}\text { No, less } \\
\text { than } \\
\text { expecting }\end{array}$ & $\begin{array}{c}\text { Yes, known } \\
\text { since Feb, } \\
\text { March, or } \\
\text { Apr. }\end{array}$ & $\begin{array}{l}\text { Learned } \\
\text { more } \\
\text { recently or } \\
\text { positively } \\
\text { surprised } \\
\end{array}$ & $\begin{array}{c}\text { No, less } \\
\text { than } \\
\text { expecting } \\
\end{array}$ \\
\hline & \multicolumn{6}{|c|}{ Panel A: All households } \\
\hline $\begin{array}{l}\text { Contemporaneous } \\
\text { week }\end{array}$ & $\begin{array}{c}1.19 \\
(0.25)\end{array}$ & $\begin{array}{c}2.37 \\
(0.83)\end{array}$ & $\begin{array}{c}2.80 \\
(0.73)\end{array}$ & $\begin{array}{c}1.30 \\
(0.27)\end{array}$ & $\begin{array}{c}1.68 \\
(0.81)\end{array}$ & $\begin{array}{l}2.00 \\
(0.81)\end{array}$ \\
\hline $\begin{array}{l}\text { Four week } \\
\text { cumulative }\end{array}$ & $\begin{array}{c}3.31 \\
(0.67)\end{array}$ & $\begin{array}{c}5.13 \\
(1.74)\end{array}$ & $\begin{array}{c}6.69 \\
(2.20)\end{array}$ & $\begin{array}{c}3.42 \\
(0.93)\end{array}$ & $\begin{array}{c}1.91 \\
(2.03)\end{array}$ & $\begin{array}{c}4.52 \\
(3.10)\end{array}$ \\
\hline \multirow[t]{2}{*}{$\begin{array}{l}\text { Number of } \\
\text { households }\end{array}$} & 15,991 & 2,525 & 2,693 & 15,956 & 2,505 & 2,685 \\
\hline & \multicolumn{6}{|c|}{ Panel B: Households with sufficient liquid wealth } \\
\hline $\begin{array}{l}\text { Contemporaneous } \\
\text { week }\end{array}$ & $\begin{array}{c}0.39 \\
(0.29)\end{array}$ & $\begin{array}{c}1.07 \\
(1.18)\end{array}$ & $\begin{array}{c}2.08 \\
(1.13)\end{array}$ & $\begin{array}{c}0.59 \\
(0.31)\end{array}$ & $\begin{array}{c}0.43 \\
(1.15)\end{array}$ & $\begin{array}{c}1.35 \\
(1.24)\end{array}$ \\
\hline $\begin{array}{l}\text { Four week } \\
\text { cumulative }\end{array}$ & $\begin{array}{c}1.69 \\
(0.82)\end{array}$ & $\begin{array}{c}2.61 \\
(2.08)\end{array}$ & $\begin{array}{l}4.68 \\
(3.00)\end{array}$ & $\begin{array}{c}2.56 \\
(1.13)\end{array}$ & $\begin{array}{l}-0.58 \\
(2.58)\end{array}$ & $\begin{array}{c}1.99 \\
(4.94)\end{array}$ \\
\hline \multirow[t]{2}{*}{$\begin{array}{l}\text { Number of } \\
\text { households }\end{array}$} & 10,603 & 1,658 & 1,317 & 10,586 & 1,649 & 1,314 \\
\hline & \multicolumn{6}{|c|}{ Panel C: Households with low liquid wealth } \\
\hline $\begin{array}{l}\text { Contemporaneous } \\
\text { week }\end{array}$ & $\begin{array}{c}2.41 \\
(0.46)\end{array}$ & $\begin{array}{c}4.26 \\
(1.06)\end{array}$ & $\begin{array}{c}3.41 \\
(0.96)\end{array}$ & $\begin{array}{c}2.39 \\
(0.50)\end{array}$ & $\begin{array}{c}3.47 \\
(1.09)\end{array}$ & $\begin{array}{c}2.55 \\
(1.07)\end{array}$ \\
\hline $\begin{array}{l}\text { Four week } \\
\text { cumulative }\end{array}$ & $\begin{array}{c}5.89 \\
(1.12)\end{array}$ & $\begin{array}{c}8.89 \\
(3.03)\end{array}$ & $\begin{array}{c}8.74 \\
(3.15)\end{array}$ & $\begin{array}{c}4.51 \\
(1.58)\end{array}$ & $\begin{array}{c}5.58 \\
(3.32)\end{array}$ & $\begin{array}{c}6.89 \\
(3.99)\end{array}$ \\
\hline $\begin{array}{l}\text { Number of } \\
\text { households }\end{array}$ & 5,388 & 867 & 1,376 & 5,370 & 856 & 1,371 \\
\hline
\end{tabular}

Note: Standard errors in parentheses. The table reports the propensity to consume NCP goods out of an ESP in percent. The regressions in the first triplet of columns include fixed effects for each week in the sample and in the second triplet include fixed effects for each week for each means of receipt. All regressions include household fixed effects and are weighted by the NCP projection factor for 2008. Each sample includes only households that report receipt during the period of the experimental variation, sufficient ESP information for that specification, and meet the standard NCP static reporting requirement for the year. Calculated based on data from The Nielsen Company (US) LLC and provided by the Marketing Data Center at the University of Chicago Booth School of Business. 
ments while only 10 percent of households with sufficient liquid wealth are. In terms of the estimated coefficients, smaller samples lead to less statistical power within each level of liquidity. For households with sufficient liquid wealth, where one might expect news to carry the largest effect, there is no evidence of any role for expectations in spending responses. For households with low liquid wealth, there is some evidence that those who expected the payment have smaller spending responses, but even this is statistically weak (the strongest finding is the contemporaneous spending response between columns 1 and 2 which has a $\mathrm{t}$-statistics of 1.60).

In sum, there is no evidence that households spent the payments because they were not expecting them. Few households were surprised by the amount of the payment upon arrival, and there is a strong consumption response among those expecting the payments, and no relationship between the sign of the expectation error and the size of the spending response. Instead, these findings suggest that households with low levels of economic sophistication or planning as measured by understanding of the stimulus payment program have little ability to smooth consumption. More households with low liquidity are negatively surprised by their payments, and, while statistically weak, these households have the largest propensity to spend on arrival despite this negative surprise.

\section{Sophistication: financial planning, planners, and use of deals, specials and coupons}

This section evaluates whether lack of planning causes violations of consumption smoothing. Households that have made financial plans in the last two years smooth spending across arrival well. Might the propensit to plan be causing smoothing (and sufficient liquidity)? A small share of households that plan extensively for vacation seem to smooth consumption well. But financial planning is far more important than planning for vacation, in that spending responds to payment arrival for households that plan for vacations but not for households that have made financial plans. Finally, households that make use of specials, deals, or coupons when shopping smooth consumption significantly better than those that do not.

Lusardi (1999) theorizes that careful planning - through making better investment choices and considering the need to save - is a major determinant of wealth accumulation for retirement. Further, the paper shows evidence that differences in the propensity to plan explain a significant amount of the differences in wealth accumulation observed in the US. Ameriks, Caplin and Leahy (2003) show that households who say that they have made a financial plan have much greater financial wealth after controlling for a large set of other possible determinants of wealth accumulation (including income and many measures of traditional preferences). Finally, as noted, Reis (2006) shows that households with large costs of optimization choose to be 'inattentive savers' who follow a saving plan and optimally let consumption track income. ${ }^{20}$

Two questions were asked in the supplemental NCP survey to measure the importance of planning behavior for consumption smoothing. The first question mimics the Ameriks,

\footnotetext{
${ }^{20}$ See also Lusardi and Mitchell (2007), and these results relate to those in both Agarwal et al. (2009), which shows a link between ability and financial mistakes, and Grinblatt, Keloharju and Linnainmaa (2011) which shows a positive relationship between IQ and stock market participation.
} 
Table 6-Spending Responses by LiQuidity and the Propensity to Plan Financially

\begin{tabular}{|c|c|c|c|c|}
\hline \multirow[b]{2}{*}{$\begin{array}{c}\text { Formulated a financial plan for } \\
\text { long term future? }\end{array}$} & \multicolumn{2}{|c|}{$\begin{array}{l}\text { Using all variation in } \\
\text { time of receipt }\end{array}$} & \multicolumn{2}{|c|}{$\begin{array}{c}\text { Using only variation in } \\
\text { timing within each } \\
\text { method of receipt }\end{array}$} \\
\hline & Yes & No & Yes & No \\
\hline & \multicolumn{4}{|c|}{ Panel A: All households } \\
\hline Contemporaneous week & $\begin{array}{l}0.73 \\
(0.32)\end{array}$ & $\begin{array}{l}2.25 \\
(0.34)\end{array}$ & $\begin{array}{c}0.83 \\
(0.33)\end{array}$ & $\begin{array}{l}2.01 \\
(0.36)\end{array}$ \\
\hline t-statistic of difference & \multicolumn{2}{|c|}{3.29} & \multicolumn{2}{|c|}{2.42} \\
\hline Four week cumulative & $\begin{array}{l}1.81 \\
(0.78)\end{array}$ & $\begin{array}{l}5.76 \\
(0.90)\end{array}$ & $\begin{array}{l}1.72 \\
(1.14)\end{array}$ & $\begin{array}{c}4.71 \\
(1.18)\end{array}$ \\
\hline t-statistic of difference & \multicolumn{2}{|c|}{3.33} & \multicolumn{2}{|c|}{1.82} \\
\hline Number of households & 10,936 & 10,405 & 10,902 & 10,373 \\
\hline Contemporaneous week & $\begin{array}{c}\text { Panel B: } \\
0.27 \\
(0.37)\end{array}$ & $\begin{array}{l}\text { Iseholds } 1 \\
1.19 \\
(0.46)\end{array}$ & $\begin{array}{c}\text { sufficient } \\
0.38 \\
(0.37)\end{array}$ & $\begin{array}{l}\frac{d \text { wealth }}{1.11} \\
(0.49)\end{array}$ \\
\hline $\begin{array}{l}t \text {-statistic of difference } \\
\text { Four week cumulative }\end{array}$ & $\begin{array}{l}1.35 \\
(0.90)\end{array}$ & $\begin{array}{l}3.15 \\
(1.25)\end{array}$ & $\begin{array}{l}1.41 \\
(1.32)\end{array}$ & $\begin{array}{l}3.13 \\
(1.64)\end{array}$ \\
\hline $\begin{array}{l}\text { t-statistic of difference } \\
\text { Number of households }\end{array}$ & \multicolumn{2}{|c|}{1.17} & \multicolumn{2}{|c|}{0.82} \\
\hline & \multicolumn{4}{|c|}{ Panel C: Households with low liquid wealth } \\
\hline Contemporaneous week & $\begin{array}{l}2.03 \\
(0.65)\end{array}$ & $\begin{array}{l}3.10 \\
(0.48)\end{array}$ & $\begin{array}{l}2.06 \\
(0.70)\end{array}$ & $\begin{array}{c}2.72 \\
(0.52)\end{array}$ \\
\hline t-statistic of difference & \multicolumn{2}{|c|}{1.33} & \multicolumn{2}{|c|}{0.76} \\
\hline Four week cumulative & $\begin{array}{l}3.38 \\
(1.60)\end{array}$ & $\begin{array}{c}7.89 \\
(1.26)\end{array}$ & $\begin{array}{l}2.44 \\
(2.24)\end{array}$ & $\begin{array}{c}5.82 \\
(1.68)\end{array}$ \\
\hline t-statistic of difference & \multicolumn{2}{|c|}{2.21} & \multicolumn{2}{|c|}{1.21} \\
\hline Number of households & 2,338 & 5,318 & 2,324 & 5,297 \\
\hline
\end{tabular}

Note: Standard errors in parentheses. The table reports the propensity to consume NCP goods out of an ESP in percent. The regressions in the first pair of columns include fixed effects for each week in the sample and in the second pair include fixed effects for each week for each means of receipt. All regressions include household fixed effects and are weighted by the NCP projection factor for 2008. Each sample includes only households that report receipt during the period of the experimental variation, sufficient ESP information for that specification, and meet the standard NCP static reporting requirement for the year. Calculated based on data from The Nielsen Company (US) LLC and provided by the Marketing Data Center at the University of Chicago Booth School of Business. 
Caplin and Leahy (2003) question: "In the last few years, have you gathered together your household's financial information, reviewed it in detail, and formulated a financial plan for your household's long term future?" The second question relates not to financial planning, but to planning as a trait in another sphere, in this case for vacation: "Before going on a vacation, how much time do you spend examining where you would most like to go and what you would like to do?" with possible answers: 'A great deal of time,' 'Quite a bit of time,' 'A little time,' 'Almost no time,' and 'Do not go on vacation.' Households responding that they do not go on vacation are dropped from the analysis of this question.

Panel A of Table 6 shows that households that have made financial plans are much better at smoothing consumption than those that have not. First, note that there is a lot of variation in this question in this sample, with roughly half the households responding each way. Second, planning is highly correlated with liquidity. Panels B and C shows that 79 percent of households that plan have sufficient liquidity and 69 percent of households with sufficient liquidity plan. Panel A shows economically large differences in spending responses. For households that have formulated financial plans, the spending response is only borderline statistically significant and roughly a third as large as for those how have not planned. About three quarters of the total spending response in the sample is accounted for by households that do not make financial plans.

Finally, financial planning has some limited explanatory power beyond liquidity (Table 6, panels B and C). Among households with liquidity, those that do not plan do not smooth spending. While pairwise tests of the equality of responses are generally statistically insignificant, a test of equality of the average responses of planners equalling that of nonplanners rejects equality in both Panels B and C with 95 percent (90 percent) confidence for both contemporaneous and four week responses using all variation in timing of receipt (using only variation of timing within each means of disbursement).

Table 7 reports the results of the same analysis for vacation planning. Again, there is lots of variation in the sample, but time spent planning vacations is almost uncorrelated with liquidity. Across degrees of planning, moving across the columns, 65 percent, 68 percent, and 67 percent have sufficient liquidity. The remainder of the table presents a statistically weak case that vacation planning matters for consumption smoothing. In Panel A households that spend a great deal of time planning for vacations do not raise spending the week of arrival as much as the other households (statistically significant at the 90 percent confidence level only). The point estimates have the same pattern over the entire month, but the economic significance is smaller and larger standard errors preclude making any conclusion with confidence. Looking at households with different levels of liquidity, Panel $\mathrm{C}$ shows that, among households with low liquidity, those who spend a great deal of time planning tent to smooth spending better than others. There is no such difference for households with sufficient liquidity.

In sum, not only are the differences across vacation planners statistically weaker than the differences across financial planners, only twenty two percent of households plan a lot and smooth consumption well. Forty four percent of the sample spends "quite a bit of time" planning for vacations and these households giving this "middle" response still show a substantial spending responses similar to households that plan less.

The final variable dealing with sophistication is the extent to which households use deals, 
Table 7-SPending Responses by Liquidity and the Propensity to Plan Vacation

\begin{tabular}{|c|c|c|c|c|c|c|}
\hline \multirow[b]{2}{*}{$\begin{array}{l}\text { Before going on } \\
\text { vacation, how much } \\
\text { time planning? }\end{array}$} & \multicolumn{3}{|c|}{ Using all variation in time of receipt } & \multicolumn{3}{|c|}{$\begin{array}{l}\text { Using only variation in timing } \\
\text { within each method of receipt }\end{array}$} \\
\hline & $\begin{array}{c}\text { A great } \\
\text { deal of } \\
\text { time }\end{array}$ & $\begin{array}{l}\text { Quite a bit } \\
\text { of time }\end{array}$ & $\begin{array}{c}\text { A little } \\
\text { time or } \\
\text { Almost no } \\
\text { time } \\
\end{array}$ & $\begin{array}{c}\text { A great } \\
\text { deal of } \\
\text { time }\end{array}$ & $\begin{array}{l}\text { Quite a bit } \\
\text { of time }\end{array}$ & $\begin{array}{c}\text { A little } \\
\text { time or } \\
\text { Almost no } \\
\text { time }\end{array}$ \\
\hline & \multicolumn{6}{|c|}{ Panel A: All households } \\
\hline $\begin{array}{l}\text { Contemporaneous } \\
\text { week }\end{array}$ & $\begin{array}{c}0.66 \\
(0.49)\end{array}$ & $\begin{array}{c}1.57 \\
(0.38)\end{array}$ & $\begin{array}{c}1.87 \\
(0.48)\end{array}$ & $\begin{array}{l}0.50 \\
(0.50)\end{array}$ & $\begin{array}{c}1.49 \\
(0.41)\end{array}$ & $\begin{array}{c}1.79 \\
(0.48)\end{array}$ \\
\hline \multicolumn{2}{|c|}{$\begin{array}{l}\text { t-test of } \\
\text { teal...'='A little...' }\end{array}$} & 1.76 & & & 1.86 & \\
\hline $\begin{array}{l}\text { Four week } \\
\text { cumulative }\end{array}$ & $\begin{array}{c}2.90 \\
(1.21)\end{array}$ & $\begin{array}{c}3.24 \\
(1.02)\end{array}$ & $\begin{array}{c}3.98 \\
(1.19)\end{array}$ & $\begin{array}{c}2.00 \\
(1.63)\end{array}$ & $\begin{array}{c}3.05 \\
(1.51)\end{array}$ & $\begin{array}{c}3.01 \\
(1.50)\end{array}$ \\
\hline \multicolumn{2}{|c|}{$\begin{array}{l}\text { t-test of } \\
\text { deal...'='A little...' }\end{array}$} & 0.64 & & & 0.09 & \\
\hline \multirow{2}{*}{$\begin{array}{l}\text { Number of } \\
\text { households }\end{array}$} & 4,065 & 7,818 & 5,602 & 4,053 & 7,796 & 5,583 \\
\hline & \multicolumn{6}{|c|}{ Panel B: Households with sufficient liquid wealth } \\
\hline $\begin{array}{l}\text { Contemporaneous } \\
\text { week }\end{array}$ & $\begin{array}{l}0.00 \\
(0.57)\end{array}$ & $\begin{array}{c}0.66 \\
(0.44)\end{array}$ & $\begin{array}{l}1.03 \\
(0.64)\end{array}$ & $\begin{array}{c}0.01 \\
(0.59)\end{array}$ & $\begin{array}{c}0.79 \\
(0.47)\end{array}$ & $\begin{array}{c}0.99 \\
(0.60)\end{array}$ \\
\hline \multicolumn{2}{|c|}{$\begin{array}{c}t \text {-test of } \\
\text { 'A great deal...'='A little...' }\end{array}$} & 1.20 & & & 1.17 & \\
\hline $\begin{array}{l}\text { Four week } \\
\text { cumulative }\end{array}$ & $\begin{array}{c}2.08 \\
(1.52)\end{array}$ & $\begin{array}{c}1.40 \\
(1.26)\end{array}$ & $\begin{array}{c}2.12 \\
(1.38)\end{array}$ & $\begin{array}{l}1.63 \\
(2.03)\end{array}$ & $\begin{array}{c}2.24 \\
(1.92)\end{array}$ & $\begin{array}{l}1.65 \\
(1.69)\end{array}$ \\
\hline \multicolumn{2}{|c|}{$\begin{array}{l}\text { t-test of } \\
\text { deal...'='A little...' }\end{array}$} & 0.02 & & & 0.15 & \\
\hline \multirow{2}{*}{$\begin{array}{l}\text { Number of } \\
\text { households }\end{array}$} & 2,630 & 5,285 & 3,771 & 2,625 & 5,274 & 3,761 \\
\hline & \multicolumn{6}{|c|}{ Panel C: Households with low liquid wealth } \\
\hline $\begin{array}{l}\text { Contemporaneous } \\
\text { week }\end{array}$ & $\begin{array}{l}1.63 \\
(0.84)\end{array}$ & $\begin{array}{c}2.99 \\
(0.68)\end{array}$ & $\begin{array}{c}3.23 \\
(0.73)\end{array}$ & $\begin{array}{l}1.21 \\
(0.87)\end{array}$ & $\begin{array}{c}2.55 \\
(0.74)\end{array}$ & $\begin{array}{c}3.08 \\
(0.79)\end{array}$ \\
\hline \multicolumn{2}{|c|}{$\begin{array}{c}\text { t-test of } \\
\text { 'A great deal...'='A little...' }\end{array}$} & 1.44 & & & 1.59 & \\
\hline $\begin{array}{l}\text { Four week } \\
\text { cumulative }\end{array}$ & $\begin{array}{c}4.44 \\
(1.98)\end{array}$ & $\begin{array}{c}6.49 \\
(1.70)\end{array}$ & $\begin{array}{l}6.96 \\
(2.20)\end{array}$ & $\begin{array}{l}2.56 \\
(2.70)\end{array}$ & $\begin{array}{l}4.19 \\
(2.37)\end{array}$ & $\begin{array}{c}5.09 \\
(2.88)\end{array}$ \\
\hline \multicolumn{2}{|c|}{$\begin{array}{c}\text { t-test of } \\
\text { 'A great deal...'='A little...' }\end{array}$} & 0.85 & & & 0.02 & \\
\hline $\begin{array}{l}\text { Number of } \\
\text { households }\end{array}$ & 1,435 & 2,533 & 1,831 & 1,428 & 2,522 & 1,822 \\
\hline \multicolumn{7}{|c|}{$\begin{array}{l}\text { Note: Standard errors in parentheses. The table reports the propensity to consume NCP goods out of an ESP in percent. } \\
\text { The regressions in the first triplet of columns include fixed effects for each week in the sample and in the second triplet } \\
\text { include fixed effects for each week for each means of receipt. All regressions include household fixed effects and are } \\
\text { weighted by the NCP projection factor for 2008. Each sample includes only households that report receipt during the period } \\
\text { of the experimental variation, sufficient ESP information for that specification, and meet the standard NCP static reporting } \\
\text { requirement for the year. Calculated based on data from The Nielsen Company (US) LLC and provided by the Marketing } \\
\text { Data Center at the University of Chicago Booth School of Business. }\end{array}$} \\
\hline
\end{tabular}


specials or coupons when making NCP purchases. When households scan in individual purchased items, they are asked to input whether they used one of these discounts. For participating stores, this information is also provided by the store. I calculate the share of individual reported purchases that use deals, and split households evenly into those whose deal use is low and those whose deal use is high.

On the one hand, one might expect households that have fewer resources to spend more time on conserving them, suggesting that households that use coupons should have low liquidity and smooth spending poorly. On the other hand, if households that use coupons plan - that is, spend more time and effort optimizing - then they may not only make better use of the resources that they have but also do a better job of inter-temporal optimization and thus of consumption smoothing.

Splitting the NCP sample into high and low coupon use households (so that they are evenly split in Panel A of Table 8), high coupon use has only a correlation of 0.07 with liquidity. Among households with sufficient liquidity slightly more use coupons (Panel B), and among households with insufficient liquidity, slightly fewer use coupons (Panel C). Panel A shows however that coupon use is economically significantly and statistically significantly related to spending responses at the one week horizon, with high coupon use households smoothing spending better. At the one month horizon, the difference is statistically weaker, but the same pattern is present. Conditioning on liquidity, because it is largely uncorrelated with coupon use, does not change this ordering, but it also reduces the sample size used to estimate each coefficient, and standard errors rise as a result.

In sum, I find that financial planning is correlated with consumption smoothing, as is coupon use. But the case for an important casual role for planning as a general trait, observable in spheres of activity other than finances, is weak.

\section{Spenders, savers, self-control, and procrastination}

This section shows first that households that self-identify as the "type of household that lives for today and spends' have much larger spending response to the payment than households that identify as more patient. Second, there is an economically large but statisticallyweak higher propensity to spend on arrival among the small share of the population that frequently regrets past purchases. But this correlation does not explain much of the aggregate spending response; the other 95 percent of the population still exhibits substantial violations of consumption smoothing. Third, and also shedding light on the potential importance of self-control problems, larger delay in responding to the survey is not indicative of larger spending responses to arrival of the payment.

A substantial literature has suggested that households can be modeled either as having heterogeneous impatience or as having heterogeneous behaviors with some standard lifecycle consumers and other households simply consuming their incomes (e.g., Campbell and Mankiw, 1989; Krusell and Smith, 1998). The NCP supplemental survey asked households to characterize themselves as spenders or savers: "In general, are you or other household members the sort of people who would rather spend your money and enjoy it today or save more for the future?" with a binary choice of 'spend now' and 'save for the future.' There is lots of variation in the responses, with two thirds of households reporting that they are the 
TABLE 8-SPENDING RESPONSES By LiQUidity AND OPTIMIZATION: DEAL USE

\begin{tabular}{|c|c|c|c|c|}
\hline \multirow{2}{*}{$\begin{array}{c}\text { Share of purchases made using } \\
\text { coupons or deals }\end{array}$} & \multicolumn{2}{|c|}{$\begin{array}{l}\text { Using all variation in } \\
\text { time of receipt }\end{array}$} & \multicolumn{2}{|c|}{$\begin{array}{l}\text { Using only variation in } \\
\text { timing within each } \\
\text { method of receipt }\end{array}$} \\
\hline & Low & High & Low & High \\
\hline & \multicolumn{4}{|c|}{ Panel A: All households } \\
\hline Contemporaneous week & $\begin{array}{l}2.08 \\
(0.34)\end{array}$ & $\begin{array}{c}0.84 \\
(0.31)\end{array}$ & $\begin{array}{c}2.14 \\
(0.36)\end{array}$ & $\begin{array}{c}0.55 \\
(0.32)\end{array}$ \\
\hline t-stat of difference & \multicolumn{2}{|c|}{2.71} & \multicolumn{2}{|c|}{3.30} \\
\hline $\begin{array}{l}\text { Four week } \\
\text { cumulative increase }\end{array}$ & $\begin{array}{c}4.61 \\
(0.83)\end{array}$ & $\begin{array}{c}2.96 \\
(0.85)\end{array}$ & $\begin{array}{c}4.39 \\
(1.18)\end{array}$ & $\begin{array}{c}1.81 \\
(1.12)\end{array}$ \\
\hline$t$-stat of difference & \multicolumn{2}{|c|}{1.38} & \multicolumn{2}{|c|}{1.59} \\
\hline \multirow[t]{2}{*}{ Number of households } & 10,666 & 10,663 & 10,631 & 10,632 \\
\hline & \multicolumn{4}{|c|}{ Panel B: Households with sufficient liquid wealth } \\
\hline Contemporaneous week & $\begin{array}{l}0.85 \\
(0.44)\end{array}$ & $\begin{array}{l}0.43 \\
(0.37)\end{array}$ & $\begin{array}{c}1.03 \\
(0.45)\end{array}$ & $\begin{array}{c}0.27 \\
(0.38)\end{array}$ \\
\hline$t$-stat of difference & \multicolumn{2}{|c|}{0.72} & \multicolumn{2}{|c|}{1.29} \\
\hline $\begin{array}{l}\text { Four week } \\
\text { cumulative increase }\end{array}$ & $\begin{array}{c}2.39 \\
(1.08)\end{array}$ & $\begin{array}{l}1.71 \\
(0.99)\end{array}$ & $\begin{array}{c}3.02 \\
(1.59)\end{array}$ & $\begin{array}{l}1.05 \\
(1.29)\end{array}$ \\
\hline t-stat of difference & \multicolumn{2}{|c|}{0.46} & \multicolumn{2}{|c|}{0.96} \\
\hline \multirow[t]{2}{*}{ Number of households } & 6,172 & 7,506 & 6,156 & 7,491 \\
\hline & \multicolumn{4}{|c|}{ Panel C: Households with low liquid wealth } \\
\hline Contemporaneous week & $\begin{array}{c}3 . \overline{49} \\
(0.53)\end{array}$ & $\begin{array}{l}1.57 \\
(0.54)\end{array}$ & $\begin{array}{c}3.39 \\
(0.57)\end{array}$ & $\begin{array}{l}1.07 \\
(0.59)\end{array}$ \\
\hline$t$-stat of difference & \multicolumn{2}{|c|}{2.55} & \multicolumn{2}{|c|}{2.83} \\
\hline $\begin{array}{l}\text { Four week } \\
\text { cumulative increase }\end{array}$ & $\begin{array}{c}7.24 \\
(1.30)\end{array}$ & $\begin{array}{c}5.34 \\
(1.60)\end{array}$ & $\begin{array}{c}5.81 \\
(1.75)\end{array}$ & $\begin{array}{l}3.31 \\
(2.16)\end{array}$ \\
\hline t-stat of difference & \multicolumn{2}{|c|}{0.92} & \multicolumn{2}{|c|}{0.90} \\
\hline Number of households & 4,494 & 3,157 & 4,475 & 3,141 \\
\hline
\end{tabular}

Note: Standard errors in parentheses. The table reports the propensity to consume NCP goods out of an ESP in percent. The regressions in the first pair of columns include fixed effects for each week in the sample and in the second pair include fixed effects for each week for each means of reciept. All regressions include household fixed effects and are weighted by the NCP projection factor for 2008. Each sample includes only households that report receipt during the period of the experimental variation, sufficient ESP information for that specification, and meet the standard NCP static reporting requirement for the year. Calculated based on data from The Nielsen Company (US) LLC and provided by the Marketing Data Center at the University of Chicago Booth School of Business.

type to save for the future. Low liquidity is significantly correlated with being a spender, a correlation of 0.31. Causation of course could run in either direction, but the phrasing as the "type of people" was designed to avoid households simply responding based on current behavior.

Consistent with persistent differences in households, households that report being the type of people who spend and enjoy today have much larger spending response than those 
that report being the type who save. Table 9 Panel A shows that the self-reported spending types exhibit large violations of consumption smoothing; the self-reported saving types smooth consumption the week of arrival but still show a statistically significant spending response over the month following arrival that is about half the size of the self-reported spending types. In the week of arrival, saving types have an economically small and statistically insignificant increase in spending, spending types have a statistically significant and three times larger increase in spending. Over a month, the cumulative spending of spending types is estimated to be double that of saving types, but this difference is not statistically significant.

Panel B and C of Table 9 show that this pattern continues to hold among households with low liquidity, but the only statistically significant (at the 90 percent level) differences are found for households with low liquidity the week the payment arrives. Among households with sufficient liquid wealth, there is little evidence of greater spending by households who characterize themselves as spenders.

Another possible reason for spending payments when they arrive is that some households have difficulty not spending liquidity. For example, one theory suggests that some households spend more of the payment on arrival than they would have chosen to had they been able to commit not to spend as much at an earlier time (see Angeletos et al., 2001; Gul and Pesendorfer, 2004a,b). I investigate this proposition in two ways.

First, to investigate whether differences in the degree to which households perceive their past spending to be suboptimal, households were asked "Many people sometimes buy things that they later wish they had not bought. About how often do you or other household members make purchases that you later regret?" and households could answer: Often, Occasionally, Rarely, or Never. Panel A of Table 10 shows that there is significant variation in the population in response to this question. About forty percent of households regret purchases often or occasionally, while 60 percent do so rarely or never. But the variation is almost unrelated to liquidity. And frequency of regret explains little of the differences in spending responses across households.

The contemporaneous response to the arrival of the payment is almost identical between households who often or occasionally regret purchases (columns 2 and 5) and those who rarely/never do (columns 3 and 6). Columns 1 and 4 break out only those households who say that they often regret past purchases. Among this small set of households, the contemporaneous and cumulative spending responses are economically much larger, but the contemporaneous responses are only borderline statistically significantly different from zero and the cumulative responses are statistically even weaker.

Panels B and C show variation conditional on sufficient liquidity and low liquidity. Panel $\mathrm{C}$ shows that there is no evidence for a role of regret in spending responses for households with low liquid wealth. However in Panel B, there is some evidence that households that rarely or never regret past purchases increase spending more in response to payment arrival than households that regret purchases more often. The estimates are economically large, but the small samples preclude confidence.

While this pattern is evidence against an important role for sophisticated models of selfcontrol, or at least against the existence of a significant number of households who have not successfully managed their issues of self-control, this evidence may not be inconsistent 
TABLE 9-SPENDING RESPONSES By LIQUIDITY AND GRASSHOPPERS AND ANTS

\begin{tabular}{|c|c|c|c|c|}
\hline \multirow[b]{2}{*}{$\begin{array}{c}\text { The sort of people who spend } \\
\text { or save? }\end{array}$} & \multicolumn{2}{|c|}{$\begin{array}{c}\text { Using all variation in time } \\
\text { of receipt }\end{array}$} & \multicolumn{2}{|c|}{$\begin{array}{l}\text { Using only variation in timing } \\
\text { within each method of receipt }\end{array}$} \\
\hline & Spend now & $\begin{array}{l}\text { Save for } \\
\text { future }\end{array}$ & Spend now & $\begin{array}{c}\text { Save for } \\
\text { future }\end{array}$ \\
\hline Contemporaneous week & $\begin{array}{l}2.37 \\
(0.39)\end{array}$ & $\begin{array}{l}\text { Panel A: } \\
0.92 \\
(0.28)\end{array}$ & $\begin{array}{c}\text { households } \\
2.19 \\
(0.43)\end{array}$ & $\begin{array}{c}0.92 \\
(0.29)\end{array}$ \\
\hline $\begin{array}{l}\quad t \text {-stat of difference } \\
\text { Four week } \\
\text { cumulative increase }\end{array}$ & $\begin{array}{c}5.14 \\
(1.05)\end{array}$ & $\begin{array}{c}2.96 \\
(0.71)\end{array}$ & $\begin{array}{l}4.09 \\
(1.40)\end{array}$ & $\begin{array}{c}2.71 \\
(1.00)\end{array}$ \\
\hline $\begin{array}{l}t \text {-stat of difference } \\
\text { Number of households }\end{array}$ & 7,881 & 13,460 & 7,852 & 13,423 \\
\hline Contemporaneous week & $\begin{array}{l}0 . \text { Panel } \\
0.90 \\
(0.55)\end{array}$ & $\begin{array}{c}\text { Households } \\
0.52 \\
(0.33)\end{array}$ & $\frac{h \text { sufficient li }}{0.85}$ & $\begin{array}{c}\frac{d \text { wealth }}{0.58} \\
(0.34)\end{array}$ \\
\hline $\begin{array}{l}\quad t \text {-stat of difference } \\
\text { Four week } \\
\text { cumulative increase }\end{array}$ & $\begin{array}{c}2.53 \\
(1.60)\end{array}$ & $\begin{array}{c}1.84 \\
(0.81)\end{array}$ & $\begin{array}{l}1.65 \\
(2.20)\end{array}$ & $\begin{array}{c}2.25 \\
(1.14)\end{array}$ \\
\hline $\begin{array}{l}t \text {-stat of difference } \\
\text { Number of households }\end{array}$ & 0.38 & 10,157 & \multicolumn{2}{|c|}{0.24} \\
\hline Contemporaneous week & $\begin{array}{c}3.36 \\
(0.54)\end{array}$ & $\begin{array}{c}\text { C: Househol } \\
1.92 \\
(0.54)\end{array}$ & $\begin{array}{c}\text { with low liqu } \\
3.05 \\
(0.59)\end{array}$ & $\begin{array}{c}\text { vealth } \\
1.74 \\
(0.57)\end{array}$ \\
\hline $\begin{array}{l}\quad t \text {-stat of difference } \\
\text { Four week } \\
\text { cumulative increase }\end{array}$ & $\begin{array}{l}7.01 \\
(1.39)\end{array}$ & $\begin{array}{c}5.92 \\
(1.43)\end{array}$ & $\begin{array}{c}5.60 \\
(1.82)\end{array}$ & $\begin{array}{c}3.64 \\
(2.03)\end{array}$ \\
\hline $\begin{array}{l}\text { t-stat of difference } \\
\text { Number of households }\end{array}$ & \multicolumn{2}{|c|}{0.55} & \multicolumn{2}{|c|}{0.72} \\
\hline
\end{tabular}

Note: Standard errors in parentheses. The table reports the propensity to consume NCP goods out of an ESP in percent. The regressions in the first pair of columns include fixed effects for each week in the sample and in the second pair include fixed effects for each week for each means of reciept. All regressions include household fixed effects and are weighted by the NCP projection factor for 2008. Each sample includes only households that report receipt during the period of the experimental variation, sufficient ESP information for that specification, and meet the standard NCP static reporting requirement for the year. Calculated based on data from The Nielsen Company (US) LLC and provided by the Marketing Data Center at the University of Chicago Booth School of Business. 
TABLE 10-SPENDING RESPONSES By LIQUIDITY AND SELF-CONTROL: REGRET OF PURCHASES

\begin{tabular}{|c|c|c|c|c|c|c|}
\hline \multirow{2}{*}{$\begin{array}{c}\text { About how often } \\
\text { do you or other } \\
\text { household } \\
\text { members make } \\
\text { purchases that } \\
\text { you later regret? }\end{array}$} & \multicolumn{3}{|c|}{ Using all variation in time of receipt } & \multicolumn{3}{|c|}{$\begin{array}{l}\text { Using only variation in timing } \\
\text { within each method of receipt }\end{array}$} \\
\hline & Often & $\begin{array}{c}\text { Often or } \\
\text { Occasionally }\end{array}$ & $\begin{array}{c}\text { Rarely or } \\
\text { Never } \\
\end{array}$ & Often & $\begin{array}{c}\text { Often or } \\
\text { Occasionally } \\
\end{array}$ & $\begin{array}{c}\text { Rarely or } \\
\text { Never }\end{array}$ \\
\hline & \multicolumn{6}{|c|}{ Panel A: All households } \\
\hline $\begin{array}{l}\text { Contemporaneous } \\
\text { week }\end{array}$ & $\begin{array}{c}2.80 \\
(1.64)\end{array}$ & $\begin{array}{l}1.10 \\
(0.34)\end{array}$ & $\begin{array}{c}1.81 \\
(0.31)\end{array}$ & $\begin{array}{c}3.64 \\
(1.99)\end{array}$ & $\begin{array}{c}0.92 \\
(0.38)\end{array}$ & $\begin{array}{l}1.80 \\
(0.33)\end{array}$ \\
\hline \multicolumn{2}{|c|}{$t$-statistic of difference } & \multicolumn{2}{|c|}{1.53} & & \multicolumn{2}{|c|}{1.77} \\
\hline $\begin{array}{l}\text { Four week } \\
\text { cumulative }\end{array}$ & $\begin{array}{c}7.54 \\
(4.83)\end{array}$ & $\begin{array}{c}3.61 \\
(0.96)\end{array}$ & $\begin{array}{l}4.04 \\
(0.76)\end{array}$ & $\begin{array}{c}7.44 \\
(7.06)\end{array}$ & $\begin{array}{c}2.83 \\
(1.29)\end{array}$ & $\begin{array}{l}3.61 \\
(1.07)\end{array}$ \\
\hline \multicolumn{2}{|c|}{$t$-statistic of difference } & \multicolumn{2}{|c|}{0.35} & & \multicolumn{2}{|c|}{0.47} \\
\hline \multirow[t]{2}{*}{$\begin{array}{l}\text { Number of } \\
\text { households }\end{array}$} & 481 & 8,426 & 12,915 & 479 & 8,399 & 12,876 \\
\hline & \multicolumn{6}{|c|}{ Panel B: Households with sufficient liquid wealth } \\
\hline $\begin{array}{l}\text { Contemporaneous } \\
\text { week }\end{array}$ & $\begin{array}{l}1.27 \\
(2.77)\end{array}$ & $\begin{array}{c}0.27 \\
(0.45)\end{array}$ & $\begin{array}{c}0.83 \\
(0.37)\end{array}$ & $\begin{array}{c}2.77 \\
(3.25)\end{array}$ & $\begin{array}{c}0.10 \\
(0.49)\end{array}$ & $\begin{array}{l}0.97 \\
(0.37)\end{array}$ \\
\hline \multicolumn{2}{|c|}{ t-statistic of difference } & \multicolumn{2}{|c|}{0.96} & & \multicolumn{2}{|c|}{1.42} \\
\hline $\begin{array}{l}\text { Four week } \\
\text { cumulative }\end{array}$ & $\begin{array}{l}10.80 \\
(8.54)\end{array}$ & $\begin{array}{c}3.29 \\
(1.27)\end{array}$ & $\begin{array}{l}1.37 \\
(0.90)\end{array}$ & $\begin{array}{c}9.81 \\
(12.40)\end{array}$ & $\begin{array}{c}2.64 \\
(1.72)\end{array}$ & $\begin{array}{l}1.78 \\
(1.28)\end{array}$ \\
\hline \multicolumn{2}{|c|}{$t$-statistic of difference } & \multicolumn{2}{|c|}{1.23} & & \multicolumn{2}{|c|}{0.40} \\
\hline \multirow[t]{2}{*}{$\begin{array}{l}\text { Number of } \\
\text { households }\end{array}$} & 221 & 4,927 & 8,758 & 221 & 4,917 & 8,737 \\
\hline & \multicolumn{6}{|c|}{ Panel C: Households with low liquid wealth } \\
\hline $\begin{array}{l}\text { Contemporaneous } \\
\text { week }\end{array}$ & $\begin{array}{c}4.17 \\
(2.03)\end{array}$ & $\begin{array}{c}2.02 \\
(0.52)\end{array}$ & $\begin{array}{c}3.49 \\
(0.57)\end{array}$ & $\begin{array}{c}4.40 \\
(2.61)\end{array}$ & $\begin{array}{c}1.77 \\
(0.57)\end{array}$ & $\begin{array}{l}3.24 \\
(0.62)\end{array}$ \\
\hline \multicolumn{2}{|c|}{$t$-statistic of difference } & \multicolumn{2}{|c|}{1.91} & & \multicolumn{2}{|c|}{1.75} \\
\hline $\begin{array}{l}\text { Four week } \\
\text { cumulative }\end{array}$ & $\begin{array}{c}7.20 \\
(5.82)\end{array}$ & $\begin{array}{c}4.32 \\
(1.48)\end{array}$ & $\begin{array}{c}8.68 \\
(1.38)\end{array}$ & $\begin{array}{c}6.98 \\
(8.15)\end{array}$ & $\begin{array}{c}2.93 \\
(1.97)\end{array}$ & $\begin{array}{c}6.65 \\
(1.89)\end{array}$ \\
\hline \multicolumn{2}{|c|}{$t$-statistic of difference } & \multicolumn{2}{|c|}{2.15} & & \multicolumn{2}{|c|}{1.36} \\
\hline $\begin{array}{l}\text { Number of } \\
\text { households }\end{array}$ & 260 & 3,499 & 4,157 & 258 & 3,482 & 4,139 \\
\hline
\end{tabular}

Note: Standard errors in parentheses. The table reports the propensity to consume NCP goods out of an ESP in percent. The regressions in the first triplet of columns include fixed effects for each week in the sample and in the second triplet include fixed effects for each week for each means of receipt. All regressions include household fixed effects and are weighted by the NCP projection factor for 2008. Each sample includes only households that report receipt during the period of the experimental variation, sufficient ESP information for that specification, and meet the standard NCP static reporting requirement for the year. Calculated based on data from The Nielsen Company (US) LLC and provided by the Marketing Data Center at the University of Chicago Booth School of Business. 
with the existence of some households that are naive about their self control problems (Akerlof, 1991; O'Donoghue and Rabin, 1999). That is, if the primary source of variation were not problems of self-control, but instead the perceptions of them and therefore the wherewithal to manage them, then a response of never or rarely regretting would signal lack of understanding and lack of management of self-control problems.

As a second approach, I estimate whether the spending response is higher for households that delay responding to the supplemental survey, relative to households that respond rapidly. Households that delay response may have more problems of short-term self-control. Dividing the sample into three groups whose responses to the survey were rapid, medium and slow, reveals almost no correlation between delay in survey response and liquidity. ${ }^{21}$ Not only is there no evidence that procrastination is associated with worse consumption smoothing but there is some statistically weak evidence that, households who procrastinate responding to the survey have slightly lower spending responses. Among households with sufficient liquidity, only those who respond to the survey in a middling amount of time spend significant amount on arrival. Among households with low liquidity, there is no detectable pattern.

In sum, while there is statistically weak evidence that there is a small portion of the population with ex-post perceived self-control problems who also have large spending responses to liquidity, there is no evidence that theories of hyperbolic discounting or self-control explain a significant portion of the observed differences in spending responses in this natural experiment for the two measures studied here.

\section{Conclusion and discussion of results}

This evidence has several implications for the modeling of consumption and saving behavior, summarized in Table 11.

This paper shows that household beliefs were not an important determinant of the month to month increase in household spending caused by the arrival of stimulus payments in 2008. The economic stimulus payments of 2008 were widely anticipated and their arrival caused significant spending increases even among households anticipating the payments.

The significant average response to the (largely expected) payments is almost entirely due to the behavior of the subpopulation of households that have low levels of liquidity, less than two months' worth of income. Thus, on one level, the view that households smooth consumption across predictable changes in income subject only to the financial friction posed by a borrowing constraint receives significant support.

However, spending responses are persistent across years rather than being reflections only of transitory economics circumstances, such moderate income shocks or temporal management of illiquid assets. Low income two years prior to the payments is highly correlated with large spending responses to the payments. Income growth, although not measured precisely, explains almost none of the variation in spending response. While this persistence could be due to budget constraints, say through means-tested assistance programs,

\footnotetext{
${ }^{21} \mathrm{~A}$ table with the regression results is contained in the unpublished appendix. I divide households into rapid, medium, and slow responders depending on whether they respond the day of the survey, in days 1-7, or after 8 of more days for email surveys, and in the first 5 days, in days 6 to 12, and after 13 or more days for mail surveys.
} 
TABLE 11-SPENDING RESPONSES BY LIQUIDITY AND SELF CONTROL: REGRET OF PURCHASES

\begin{tabular}{|c|c|c|c|c|c|}
\hline Factor & $\begin{array}{l}\text { Correlated } \\
\text { with a higher } \\
\text { propensity to } \\
\text { spend? }\end{array}$ & $\begin{array}{c}\text { Correlation } \\
\text { with low } \\
\text { liquidity }\end{array}$ & $\begin{array}{l}\text { If correlat } \\
\text { liqu } \\
\text { Explanation } \\
\text { under } \\
\text { textbook } \\
\text { buffer stock } \\
\text { theory }\end{array}$ & $\begin{array}{l}\frac{\text { ed with low }}{\text { lidity }} \\
\text { Alternative } \\
\text { explanation of } \\
\text { spending } \\
\text { response }\end{array}$ & $\begin{array}{l}\frac{\text { Independent }}{\text { channel }} \\
\text { Is there } \\
\text { correlation } \\
\text { conditional on } \\
\text { liquidity? }\end{array}$ \\
\hline $\begin{array}{l}\text { Decrease in income } \\
\text { (poorly measured) }\end{array}$ & No & & & & \\
\hline $\begin{array}{l}\text { Less than median } \\
\text { income (2006) }\end{array}$ & Yes & 0.13 & $\begin{array}{l}\text { Means- } \\
\text { testing or } \\
\text { impatience }\end{array}$ & $\begin{array}{l}\text { Ability to earn } \\
\text { and smooth }\end{array}$ & $\begin{array}{c}\text { Yes, channel like } \\
\text { sophistication, } \\
\text { ability }\end{array}$ \\
\hline $\begin{array}{l}\text { Positive news on } \\
\text { arrival }\end{array}$ & No & -0.01 & & & No \\
\hline $\begin{array}{l}\text { Unexpected or } \\
\text { less than expected }\end{array}$ & Yes, insignif & 0.08 & & & $\begin{array}{c}\text { Possibly, channel } \\
\text { like } \\
\text { sophistication }\end{array}$ \\
\hline $\begin{array}{l}\text { Lack of financial } \\
\text { planning }\end{array}$ & Yes & 0.31 & $\begin{array}{l}\text { Low wealth } \\
\text { implies little } \\
\text { need to plan }\end{array}$ & $\begin{array}{c}\text { Planning } \\
\text { causes saving, } \\
\text { smoothing }\end{array}$ & $\begin{array}{c}\text { Yes, but not } \\
\text { statistically } \\
\text { strong }\end{array}$ \\
\hline $\begin{array}{l}\text { Little/no vacation } \\
\text { planning }\end{array}$ & $\begin{array}{l}\text { Weak, week } \\
\text { of arrival only }\end{array}$ & -0.01 & & & \\
\hline $\begin{array}{l}\text { Low use of } \\
\text { specials, deals }\end{array}$ & $\begin{array}{l}\text { Yes, week of } \\
\text { arrival only }\end{array}$ & 0.13 & $\begin{array}{l}\text { Poor have } \\
\text { little time }\end{array}$ & $\begin{array}{l}\text { Optimization } \\
\text { over goods } \\
\text { and time }\end{array}$ & $\begin{array}{c}\text { Yes only week of } \\
\text { arrival, low } \\
\text { liquidity }\end{array}$ \\
\hline Spender household & Yes & 0.31 & $\begin{array}{l}\text { Impatience } \\
\text { causes low } \\
\text { liquidity }\end{array}$ & $\begin{array}{l}\text { Some } \\
\text { households are } \\
\text { hand-to-mouth }\end{array}$ & $\begin{array}{c}\text { Yes only week of } \\
\text { arrival, low } \\
\text { liquidity }\end{array}$ \\
\hline $\begin{array}{l}\text { Often regret } \\
\text { purchases }\end{array}$ & Yes, insignif & 0.06 & & & $\begin{array}{c}5 \text { percent of } \\
\text { households lack } \\
\text { self-control }\end{array}$ \\
\hline $\begin{array}{l}\text { Procrastination of } \\
\text { survey }\end{array}$ & No & -0.03 & & & \\
\hline
\end{tabular}

Note: Each variable is defined as a binary variable so that correlations are comparable. Low income is defined as less than the median income. "Yes, insignif" indicates effects that are behaviorally important but statistically insignificant. 
I also find that a number of behaviors and measures of household type are as important explanators of which households smooths spending across the arrival of liquidity. Arrival causes larger spending responses for the type of households that lives for today, for those households having made a financial plan in the last two years, and for households that using more coupons or deals when making purchases. Statically weak, arrival also causes somewhat larger spending for households that are disappointed in their payment amount, for households that do not plan for vacations, as well as for the small share of people who often regret past purchase.

A buffer stock or liquidity management model in which some households are highly impatient would match the evidence of large spending responses among households with low liquidity as identified by the saver-spender distinction. And costly investment in skills could further match the relationship between impatience and low labor income (e.g. more impatient households invest in less education). But other evidence suggests a role for sophistication or planning, which could potentially be a result of low liquidity or impatience.

Alternatively, low levels of economic sophistication or high costs of optimization may cause both low levels of liquid wealth and poor consumption smoothing. Low ability or economic sophistication is a persistent characteristic, and can cause both poor economic outcomes like wealth, income, and consumption volatility, and outcomes like lack of planning, lack of coupon use, and little understanding of payment programs like the stimulus program. In this view, high spending responses to predictable income and lack of planning, being a 'spender,' etc., are all symptoms of low levels of sophistication, for want of a better term. 


\section{REFERENCES}

Agarwal, Sumit, Chunlin Liu, and Nicholas S. Souleles. 2007. "The Response of Consumer Spending and Debt to Tax Rebates - Evidence from Consumer Credit Data." Journal of Political Economy, 115(6): 986-1019.

Agarwal, Sumit, John C. Driscoll, Xavier Gabaix, and David Laibson. 2009. "The Age of Reason: Financial Decisions over the Life Cycle and Implications for Regulation." Brookings Papers on Economic Activity, Fall(51-177).

Akerlof, George. 1991. "Procrastination and Obedience." American Economic Review, 119.

Ameriks, John, Andrew Caplin, and John Leahy. 2003. "Wealth Accumulation and the Propensity to Plan." Quarterly Journal of Economics, 118(3): 1007-1047.

Angeletos, George-Marios, David Laibson, Andrea Repetto, Jeremy Tobacman, and Stephen Weinberg. 2001. "The Hyperbolic Consumption Model: Calibration, Simulation, and Empirical Evaluation.” Journal of Economic Perspectives, 15(3): 47-68.

Bernheim, B. Douglas, Jonathan Skinner, and Steven Weinberg. 2001. "What Accounts for the Variation in Retirement Wealth among U.S. Households?" American Economic Review, 91(4): 832-857.

Bertrand, Marianne, and Adair Morse. 2009. "What do High-Interest Borrowers Do with their Tax Rebate?" American Economic Review, 99(2): 418-23.

Broda, Christian, and David E. Weinstein. 2010. "Product Creation and Destruction: Evidence and Price Implications." American Economic Review, 100(3): 691-723.

Broda, Christian, and Jonathan Parker. 2014. "The Economic Stimulus Payments of 2008 and the Aggregate Demand for Consumption." Journal of Monetary Economics, 68(S20-36).

Bureau of Labor Statistics, U.S. Department of Labor. 2009. "Consumer Expenditure Survey Results on the 2009 Economic Stimulus Payments (Tax Rebates)." Survey.

Caballero, Ricardo J. 1995. "Near Rationality, Heterogeneity, and Aggregate Consumption." Journal of Money, Credit, and Banking, 27(1): 29-48.

Campbell, John Y., and N. Gregory Mankiw. 1989. "Consumption, Income, and Interest Rates: Reinterpreting the Time Series Evidence." in Olivier Jean Blanchard and Stanley Fischer eds. NBER Macroeconomics Annual.

Carroll, Christopher D. 1997. "Buffer-Stock Saving and the Life Cycle/Permanent Income Hypothesis." The Quarterly Journal of Economics, 112(1): 1-55.

Chetty, Raj, John Friedman, Søren Leth-Petersen, Torben Nielsen, and Tore Olsen. 2014. "Active vs. Passive Decisions and Crowd-Out in Retirement Savings Accounts: Evidence from Denmark." Quarterly Journal of Economics, 129(3): 1141-1219. 
Choi, James J., David Laibson, and Brigitte C. Madrian. 2009. "Mental Accounting in Portfolio Choice: Evidence from a Flypaper Effect." American Economic Review, 99(5): 2085-95.

Deaton, Angus. 1991. "Saving and Liquidity Constraints." Econometrica, 59(5): 12211248.

Di Maggio, Marco, Amir Kermani, and Rodney Ramcharan. 2015. "Monetary Policy Pass-Through: Household Consumption and Voluntary Deleveraging." Society for Economic Dynamics 2015 Meeting Papers 256.

Grinblatt, Mark, Matti Keloharju, and Juhani Linnainmaa. 2011. "IQ and Stock Market Participation." The Journal of Finance, 66(6): 2121-2164.

Gross, David B., and Nicholas S. Souleles. 2002. "Do Liquidity Constraints and Interest Rates Matter for Consumer Behavior? Evidence from Credit Card Data." The Quarterly Journal of Economics, 117(1): 149-185.

Gross, Tal, Matthew J. Notowidigdo, and Jialan Wang. 2014. "Liquidity Constraints and Consumer Bankruptcy: Evidence from Tax Rebates." The Review of Economics and Statistics, 96(3): 431-443.

Gul, Faruk, and Wolfgang Pesendorfer. 2004a. "Self-Control and the Theory of Consumption." Econometrica, 72(1): 119-158.

Gul, Faruk, and Wolfgang Pesendorfer. 2004b. "Self Control, Revealed Preferences and Consumption Choice.” Review of Economic Dynamics, 7(2): 243-264.

Hurst, Erik. 2003. "Grasshoppers, Ants, and Pre-Retirement Wealth: A Test of Permanent Income.” National Bureau of Economic Research, Inc NBER Working Papers 10098.

Internal Revenue Service, U.S. Department of the Treasury. 2008. "IRS Announces Economic Stimulus Payment Schedules, Provides Online Payment Calculator."

Jappelli, Tullio. 1990. "Who is Credit Constrained in the U. S. Economy?" The Quarterly Journal of Economics, 105(1): 219-234.

Jappelli, Tullio, and Luigi Pistaferri. 2014. "Fiscal Policy and MPC Heterogeneity." American Economic Journal: Macroeconomics, 6(4): 107-36.

Jappelli, Tullio, Jörn-Steffen Pischke, and Nicholas S. Souleles. 1998. "Testing For Liquidity Constraints In Euler Equations With Complementary Data Sources." The Review of Economics and Statistics, 80(2): 251-262.

Johnson, David S., Jonathan A. Parker, and Nicholas S. Souleles. 2006. "Household Expenditure and the Income Tax Rebates of 2001." American Economic Review, 96(5): 1589-1610.

Kaplan, Greg, and Giovanni L. Violante. 2014. "A Model of the Consumption Response to Fiscal Stimulus Payments.” Econometrica, 82(4): 1199-1239. 
Keys, Benjamin J., Tomasz Piskorski, Amit Seru, and Vincent Yao. 2014. "Mortgage Rates, Household Balance Sheets, and the Real Economy." National Bureau of Economic Research Working Paper 20561.

Krusell, Per, and Anthony A. Smith, Jr. 1998. "Income and Wealth Heterogeneity in the Macroeconomy." Journal of Political Economy, 106(5): 867-896.

Ludvigson, Sydney. 1999. "Consumption and credit: a model of time-varying liquidity constraints." The Review of Economics and Statistics, 81(3): 434-447.

Lusardi, Annamaria. 1999. Behavioral Dimensions of Retirement Economics. New York: Brookings Institution/Russell Sage Foundation.

Lusardi, Annamaria, and Olivia S. Mitchell. 2007. "Baby Boomer retirement security: The roles of planning, financial literacy, and housing wealth." Journal of Monetary Economics, 54(1): 205-224.

O'Donoghue, Ted, and Matthew Rabin. 1999. "Doing It Now or Later." The American Economic Review, 89(1): 103-124.

Parker, Jonathan A. 1999. "The Reaction of Household Consumption to Predictable Changes in Social Security Taxes." The American Economic Review, 89(4): 959-973.

Parker, Jonathan A., Nicholas S. Souleles, David S. Johnson, and Robert McClelland. 2013. "Consumer Spending and the Economic Stimulus Payments of 2008." American Economic Review, 103(6): 2530-53.

Reis, Ricardo. 2006. "Inattentive consumers." Journal of Monetary Economics, 53(8): 1761-1800.

Sahm, Claudia R., Matthew D. Shapiro, and Joel Slemrod. 2010. "Household Response to the 2008 Tax Rebate: Survey Evidence and Aggregate Implications." In Tax Policy and the Economy, Volume 24. NBER Chapters, 69-110. National Bureau of Economic Research, Inc.

Shapiro, Matthew D., and Joel Slemrod. 1995. "Consumer Response to the Timing of Income: Evidence from a Change in Tax Withholding." The American Economic Review, 85(1): 274-283.

Sims, Christopher A. 2003. "Implications of rational inattention." Journal of Monetary Economics, 50(3): 665-690.

Souleles, Nicholas S. 1999. "The Response of Household Consumption to Income Tax Refunds.” American Economic Review, 89(4): 947-958.

Souleles, Nicholas S. 2000. "College tuition and household savings and consumption." Journal of Public Economics, 77(2): 185-207.

Stephens, Jr., Melvin. 2003. "3rd of tha Month: Do Social Security Recipients Smooth Consumption Between Checks?” American Economic Review, 93(1): 406-422. 
Stephens, Jr., Melvin. 2008. "The Consumption Response to Predictable Changes in Discretionary Income: Evidence from the Repayment of Vehicle Loans." The Review of Economics and Statistics, 90(2): 241-252.

Zeldes, Stephen P. 1989a. "Consumption and Liquidity Constraints: An Empirical Investigation.” Journal of Political Economy, 97(2): 305-346.

Zeldes, Stephen P. 1989b. "Optimal Consumption with Stochastic Income: Deviations from Certainty Equivalence.” The Quarterly Journal of Economics, 104(2): 275-298. 